Biogeosciences, 10, 2331-2345, 2013

www.biogeosciences.net/10/2331/2013/

doi:10.5194/bg-10-2331-2013

(C) Author(s) 2013. CC Attribution 3.0 License.

(c) (i)

\title{
Response of halocarbons to ocean acidification in the Arctic
}

\author{
F. E. Hopkins ${ }^{1}$, S. A. Kimmance ${ }^{1}$, J. A. Stephens ${ }^{1}$, R. G. J. Bellerby ${ }^{2,3,4}$, C. P. D. Brussaard ${ }^{5}$, J. Czerny ${ }^{6}$, \\ K. G. Schulz ${ }^{6}$, and S. D. Archer ${ }^{1,7}$ \\ ${ }^{1}$ Plymouth Marine Laboratory, Plymouth, UK \\ ${ }^{2}$ Norwegian Institute for Water Research, Bergen, Norway \\ ${ }^{3}$ Uni Bjerknes Centre, Uni Research AS, Bergen, Norway \\ ${ }^{4}$ Geophysical Institute, University of Bergen, Bergen, Norway \\ ${ }^{5}$ Royal Netherlands Institute for Sea Research (NIOZ), Texel, the Netherlands \\ ${ }^{6}$ Helmholtz Centre for Ocean Research (GEOMAR), Kiel, Germany \\ ${ }^{7}$ Bigelow Laboratory for Ocean Sciences, Maine, USA
}

Correspondence to: F. E. Hopkins (fhop@pml.ac.uk)

Received: 24 May 2012 - Published in Biogeosciences Discuss.: 9 July 2012

Revised: 13 March 2013 - Accepted: 18 March 2013 - Published: 8 April 2013

\begin{abstract}
The potential effect of ocean acidification (OA) on seawater halocarbons in the Arctic was investigated during a mesocosm experiment in Spitsbergen in June-July 2010. Over a period of 5 weeks, natural phytoplankton communities in nine $\sim 50 \mathrm{~m}^{3}$ mesocosms were studied under a range of $p \mathrm{CO}_{2}$ treatments from $\sim 185 \mu \mathrm{atm}$ to $\sim 1420 \mu \mathrm{atm}$. In general, the response of halocarbons to $p \mathrm{CO}_{2}$ was subtle, or undetectable. A large number of significant correlations with a range of biological parameters (chlorophyll $a$, microbial plankton community, phytoplankton pigments) were identified, indicating a biological control on the concentrations of halocarbons within the mesocosms. The temporal dynamics of iodomethane $\left(\mathrm{CH}_{3} \mathrm{I}\right)$ alluded to active turnover of this halocarbon in the mesocosms and strong significant correlations with biological parameters suggested a biological source. However, despite a $p \mathrm{CO}_{2}$ effect on various components of the plankton community, and a strong association between $\mathrm{CH}_{3} \mathrm{I}$ and biological parameters, no effect of $p \mathrm{CO}_{2}$ was seen in $\mathrm{CH}_{3} \mathrm{I}$. Diiodomethane $\left(\mathrm{CH}_{2} \mathrm{I}_{2}\right)$ displayed a number of strong relationships with biological parameters. Furthermore, the concentrations, the rate of net production and the sea-to-air flux of $\mathrm{CH}_{2} \mathrm{I}_{2}$ showed a significant positive response to $p \mathrm{CO}_{2}$. There was no clear effect of $p \mathrm{CO}_{2}$ on bromocarbon concentrations or dynamics. However, periods of significant net loss of bromoform $\left(\mathrm{CHBr}_{3}\right)$ were found to be concentration-dependent, and closely correlated with total bacteria, suggesting a degree of biological consumption of this halocarbon in Arctic waters. Although the effects of OA
\end{abstract}

on halocarbon concentrations were marginal, this study provides invaluable information on the production and cycling of halocarbons in a region of the world's oceans likely to experience rapid environmental change in the coming decades.

\section{Introduction}

Volatile marine halocarbons are produced via a range of biological and photochemical processes in the surface ocean, resulting in a strong flux to the marine atmosphere. Production processes include direct biological synthesis by phytoplankton, bacteria and macroalgae (Tokarczyk and Moore 1994; Tait and Moore, 1995; Moore et al., 1996; Manley and Cuesta, 1997; Scarratt and Moore, 1998; Amachi et al., 2001; Hughes et al., 2006), and indirect production through reactions between dissolved organic matter and light (Moore and Zafiriou, 1994; Happell and Wallace, 1996; Richter and Wallace, 2004) and/or ozone (Martino et al., 2009). Seawater concentrations of halocarbons are also controlled by a number of loss processes, including hydrolysis and nucleophilic attack (Zafiriou, 1975; Elliott and Rowland, 1993), photolysis (Jones and Carpenter, 2005; Martino et al., 2005) and bacterial assimilation (King and Saltzman, 1997; Goodwin et al., 1998, 2001). The resultant surface ocean halocarbon pool undergoes sea-air gas exchange, a flux which constitutes the most important source of natural halogens to the atmosphere. Halocarbons are rapidly oxidised in the atmosphere

Published by Copernicus Publications on behalf of the European Geosciences Union. 
to produce reactive radicals ( $\mathrm{I}, \mathrm{IO}, \mathrm{Br}, \mathrm{BrO})$ which exert an important control on ozone (Chameides and Davis, 1980; Solomon et al., 1994; Davis et al., 1996; Read et al., 2008), and act as condensation nuclei for the growth of larger particles and clouds with the potential to influence global climate (O'Dowd et al., 2002).

In the Arctic, atmospheric halogen species are implicated in ozone $\left(\mathrm{O}_{3}\right)$ depletion events (ODEs) - dramatic losses of tropospheric ozone that occur following the polar sunrise. ODEs are initiated and catalysed by photochemistry that converts inert halide salt ions (e.g. $\mathrm{Br}^{-}$) into reactive halogen species (e.g. $\mathrm{Br}$ and $\mathrm{BrO}$ ). The most extensive ODEs occur over the frozen Arctic Ocean, as sea ice surfaces, brine and frost flowers represent the main source of inorganic bromine during these events (see Simpson et al., 2007 for review). Halocarbons are considered to play an important role in both the initiation and/or the termination of Arctic reactive halogen chemistry (Simpson et al., 2007). Furthermore, results of modelling studies indicate that iodocarbons such as diiodomethane $\left(\mathrm{CH}_{2} \mathrm{I}_{2}\right)$ have a significantly greater $\mathrm{O}_{3}$ depletion effect (per molecule) than the addition of further sea-salt derived $\mathrm{Br}_{2} / \mathrm{BrCl}$ (Calvert and Lindberg, 2004). Recent work in sub-Arctic Canada has further raised the importance of halocarbons in Arctic atmospheric chemistry. A combination of Differential Optical Absorption Spectroscopy (DOAS) observations of IO and measurements of atmospheric mixing ratios of halocarbons has revealed episodes of elevated IO, accompanied by a variety of iodocarbons (Mahajan et al., 2010). Air-mass back trajectories show that the iodine compounds originated from open water polynyas in the sea ice covered Hudson Bay. Using the one-dimensional Tropospheric Halogen Chemistry Model (THAMO) (Saiz-Lopez et al., 2008), Mahajan et al. (2010) showed that iodocarbon sources from ice-free Arctic waters could account for the observed concentrations of IO. Such levels of IO deplete $\mathrm{O}_{3}$ at rates comparable to $\mathrm{BrO}$. Furthermore, relatively small amounts of $\mathrm{IO}$ can cause a large increase in the $\mathrm{O}_{3}$ destruction potential of $\mathrm{BrO}$.

The Arctic region is currently experiencing rapid environmental change. Summer sea ice extent has steadily decreased over the past $30 \mathrm{yr}$, and the rate of this decline now exceeds any predictions made using IPCC AR4 simulations (Stroeve et al., 2011; Wang and Overland, 2009). The duration of melt season has increased by about 20 days over the last $30 \mathrm{yr}$ for the Arctic as a whole (Markus et al., 2009), and in areas where sea ice concentration has decreased in early summer, the timing of the annual phytoplankton blooms has become significantly earlier (Kahru et al., 2011). The Arctic region is particularly susceptible to ocean acidification (OA). Over 400 billion tons of $\mathrm{CO}_{2}$ has been released to the atmosphere by human activities over the last $200 \mathrm{yr}$, one third of which has been soaked up by the oceans (Calderia and Wickett, 2003; Sabine et al., 2004). This unprecedented influx of $\mathrm{CO}_{2}$ is resulting in an increase in $\mathrm{H}^{+}$ion concentrations manifested as a drop in surface ocean $\mathrm{pH}$, accom- panied by a decrease in the saturation state of calcium carbonate $\left(\Omega \mathrm{CaCO}_{3}\right)$. This reduces the availability of carbonate ions $\left(\mathrm{CO}_{3}^{2-}\right)$, which are a vital component of the skeletons of calcifying marine organisms (Orr et al., 2005). Due to increased $\mathrm{CO}_{2}$ solubility at lower water temperatures and a rapidly changing climate leading to land- and sea ice loss, model predictions suggest that areas of the surface Arctic Ocean will, within the next decade, be the first to experience the effects of OA (Steinacher et al., 2009).

Recently, there has been interest in how the changing Arctic climate may influence the sea-to-air flux of halocarbons. Declining sea ice extent and thickness, accompanied by an increase in open water and marine primary productivity, could result in an up-turn in the net production and resulting flux of halocarbons to the atmosphere (Mahajan et al., 2010; Shaw et al., 2011; Zhang et al., 2010). This may elevate the importance of halocarbons in Arctic atmospheric chemistry and $\mathrm{O}_{3}$ regulation. However, nothing is known of the response of marine halocarbons to OA in the Arctic, a phenomenon that will go hand-in-hand with climatic changes. Species shifts in phytoplankton (see Riebesell and Tortell, 2011 for review) and increased rates of bacterial activity (Piontek et al., 2010) are anticipated responses to future OA. Furthermore, different species of phytoplankton are known to produce differing quantities of halocarbons. Therefore, in order to gain an understanding of the future flux of marine halocarbons to the atmosphere, a whole ecosystem approach must be adopted and mesocosm experiments provide this vital platform.

Previous mesocosm experiments performed in Norwegian temperate coastal waters have given contrasting effects of OA on halocarbons. Wingenter et al. (2007) observed large increases in chloroiodomethane $\left(\mathrm{CH}_{2} \mathrm{ClI}\right)$ under $2 \times$ ambient $\mathrm{CO}_{2}(46 \pm 4 \%)$ and $3 \times$ ambient $\mathrm{CO}_{2}(131 \pm 11 \%)$ relative to ambient control mesocosms. By contrast, Hopkins et al. (2010) reported large and significant decreases in a variety of iodocarbons under high $\mathrm{CO}_{2}(\sim 750 \mu \mathrm{atm})$ relative to present day control mesocosms $(\sim 380 \mu \mathrm{atm})$, whilst the bromocarbons showed little response to the future conditions. Now, we need to understand how the net production of halocarbons from other ocean regions may respond to OA. As marine halocarbons may be key players in Arctic atmospheric chemistry now and perhaps to a greater extent in the future, the aim of this study was to investigate how their net production and subsequent sea-to-air flux may be affected by future OA.

\section{Materials and methods}

\subsection{General experimental set-up}

A mesocosm experiment was performed between 31 May and 7 July 2010 in Kongsfjorden $\left(78^{\circ} 56.2^{\prime} \mathrm{N} ; 11^{\circ} 53.6^{\prime} \mathrm{E}\right)$, on the west coast of Spitsbergen, the largest island of the 
Table 1. Mean $p \mathrm{CO}_{2}$ ( $\mu \mathrm{atm}$ ) and $\mathrm{pH}$ (on the total scale) for the halocarbon sampling period $\left(t_{4}-t_{27}\right)$ and for each phase of the experiment referred to in this article. See Bellerby et al. (2012) for full details of the evolution of the carbonate system within the mesocosms.

\begin{tabular}{|c|c|c|c|c|c|c|c|c|}
\hline & \multicolumn{2}{|c|}{$\begin{array}{c}\text { Halocarbons } \\
\text { sampling period } \\
t_{4}-t_{27}\end{array}$} & \multicolumn{2}{|c|}{$\begin{array}{c}\text { PI } \\
t_{4}-t_{12}\end{array}$} & \multicolumn{2}{|c|}{$\begin{array}{c}\text { PII } \\
t_{13}-t_{21}\end{array}$} & \multicolumn{2}{|c|}{$\begin{array}{c}\text { PIII } \\
t_{22}-t_{27}\end{array}$} \\
\hline & $\begin{array}{l}\text { Mean } \\
p \mathrm{CO}_{2} \\
(\mu \mathrm{atm})\end{array}$ & $\begin{array}{l}\text { Mean } \\
\mathrm{pH} \\
\text { (Total) }\end{array}$ & $\begin{array}{l}\text { Mean } \\
p \mathrm{CO}_{2} \\
(\mu \mathrm{atm})\end{array}$ & $\begin{array}{l}\text { Mean } \\
\mathrm{pH} \\
\text { (Total) }\end{array}$ & $\begin{array}{l}\text { Mean } \\
p \mathrm{CO}_{2} \\
(\mu \mathrm{atm})\end{array}$ & $\begin{array}{c}\text { Mean } \\
\mathrm{pH} \\
\text { (Total) }\end{array}$ & $\begin{array}{l}\text { Mean } \\
p \mathrm{CO}_{2} \\
(\mu \mathrm{atm})\end{array}$ & $\begin{array}{c}\text { Mean } \\
\mathrm{pH} \\
\text { (Total) }\end{array}$ \\
\hline M3 & 175 & 8.34 & 182 & 8.33 & 177 & 8.33 & 170 & 8.35 \\
\hline M7 & 180 & 8.33 & 184 & 8.32 & 180 & 8.33 & 170 & 8.35 \\
\hline M2 & 250 & 8.21 & 269 & 8.18 & 245 & 8.20 & 234 & 8.24 \\
\hline M4 & 340 & 8.09 & 368 & 8.06 & 347 & 8.08 & 310 & 8.13 \\
\hline M8 & 425 & 8.01 & 476 & 7.96 & 426 & 8.00 & 391 & 8.04 \\
\hline M1 & 600 & 7.87 & 684 & 7.81 & 599 & 7.87 & 534 & 7.92 \\
\hline M6 & 675 & 7.82 & 842 & 7.73 & 677 & 7.82 & 579 & 7.89 \\
\hline M5 & 860 & 7.72 & 1064 & 7.63 & 853 & 7.72 & 747 & 7.78 \\
\hline M9 & 1085 & 7.63 & 1427 & 7.51 & 1062 & 7.63 & 891 & 7.71 \\
\hline
\end{tabular}

Svalbard Archipelago. A total of nine mesocosms were deployed in the fjord, moored in sets of three with $\sim 40 \mathrm{~m}$ between each mesocosm and $\sim 50 \mathrm{~m}$ between the triplets, and each capable of enclosing $\sim 50 \mathrm{~m}^{3}$ of seawater. The mesocosms were filled with fjord water which was screened through $3 \mathrm{~mm}$ mesh to eliminate larger organisms including pteropods. On 2 June $\left(t_{-5}\right)$, the mesocosms were closed, allowing no further exchange with the surrounding fjord water. The mesocosms were fully open to the atmosphere, but were covered with a transparent protective lid to minimise external nutrient inputs from seabirds and rain. Seven of the mesocosms received varying amounts of $\mathrm{CO}_{2}$-saturated seawater over a period of 5 days $\left(t_{-1}\right.$ to $\left.t_{4}\right)$, resulting in a range of $p \mathrm{CO}_{2}$ levels, from $\sim 185$ to $1420 \mu$ atm (Phase 0 ). The two control mesocosms received no $\mathrm{CO}_{2}$ addition, and represented the in situ carbonate chemistry of the fjord (175-180 $\mu \mathrm{atm})$. Once the $p \mathrm{CO}_{2} / \mathrm{pH}$ levels had been adjusted, daily experimental sampling of the mesocosms for halocarbons began, commencing on 11 June $\left(t_{4}\right)$ and continuing until 4 July $\left(t_{27}\right)$. Table 1 gives a summary of the mean $p \mathrm{CO}_{2}$ ( $\left.\mu \mathrm{atm}\right)$ and $\mathrm{pH}$ (on the total scale) for the period $t_{4}-t_{27}$, as well as mean values for the three experimental phases that are referred to in this paper. Nutrients were added to the mesocosms on 20 June ( $\left.t_{13}\right)$ (mean concentrations: nitrate $5.56 \mu \mathrm{M}$, phosphate $0.39 \mu \mathrm{M}$, and silicate $1.47 \mu \mathrm{M}$ ). Full details of the experimental setup, evolution of the carbonate systems of the mesocosms and nutrient additions are given by Bellerby et al. (2012) and Schulz et al. (2013).

\subsection{Sampling for halocarbon compounds}

Samples for halocarbon analysis were taken using a depth integrating water sampler (IWS) (Hydrobios, Kiel, Germany) deployed from a small boat, suitable for the collection of trace gas-sensitive samples. The sampler was manually low- ered through the water column to depth, and programmed to collect a $12 \mathrm{~m}$-integrated sample. Once returned to the boat, a length of Tygon tubing was attached to the outlet at the bottom of the sampler and sub-samples for halocarbon analysis were collected in $250 \mathrm{~mL}$ amber glass-stoppered bottles. The bottle was rinsed three times before the Tygon tubing was placed to the bottom of the bottle, allowing it to gently fill and overflow three times. On the fourth filling, the bottle was filled to the top and the glass-stopper was replaced, ensuring the absence of bubbles or headspace. Samples were transported in a cool box back to the laboratory onshore, and all were analysed within $6 \mathrm{~h}$ of collection.

\subsection{Quantification of halocarbon compounds}

Seawater sub-samples were gently withdrawn from the amber glass-stoppered bottles using a $100 \mathrm{~mL}$ glass syringe and $1 / 8^{\prime \prime}$ nylon syringe extension. The sample was filtered through a $0.7 \mu \mathrm{m}$ filter (GF/F, Whatman) into a second syringe, ensuring that the introduction of bubbles into the samples was avoided at all times. Following the addition of two deuterated surrogate analytes to monitor instrument sensitivity drift (Martino et al., 2005; Hughes et al., 2006), a $40 \mathrm{~mL}$ sample was injected into a glass purge vessel, and the halocarbons were extracted by purging the seawater with ultra-high purity (BIP) nitrogen for $10 \mathrm{~min}$ at a flow rate of $90 \mathrm{~mL} \mathrm{~min}^{-1}$. Aerosols were removed from the purge gas stream using glass wool contained within a section of glass tubing, and a counterflow nafion drier using oxygen-free nitrogen at a flow rate of $180 \mathrm{~mL} \mathrm{~min}^{-1}$ was used to dry the gas. Halocarbons were trapped on triple-bed stainless steel solid sorbent tubes (Markes International Ltd.) containing Tenax, Carbograph and Carboxen, held at $1-2{ }^{\circ} \mathrm{C}$ in a custom-made peltier-cooled metal block. Sample tubes were analysed immediately after trapping using a semi-automated system 
consisting of an Agilent Gas Chromatograph-Mass Spectrometer (GC-MS), coupled to a Markes Unity thermal desorption (TD) platform. The GC was fitted with a $60 \mathrm{~m}$ DBVRX capillary column ( $0.32 \mu \mathrm{m}$ film thickness, J \& W Ltd.), and the MS was operated in electron ionization (EI)/single ion mode (SIM) throughout the analyses. Within Unity, the sample tubes were heated to $200{ }^{\circ} \mathrm{C}$ for $5 \mathrm{~min}$, and the desorbed sample was refocused on a cold trap held at $-10{ }^{\circ} \mathrm{C}$. Following this, the cold trap underwent rapid heating up to $290^{\circ} \mathrm{C}$ at a rate of $100^{\circ} \mathrm{C} \mathrm{s}^{-1}$ and the sample was introduced to the GC column using a He carrier flow rate of $2 \mathrm{~mL} \mathrm{~min}^{-1}$. The GC oven was held at $40^{\circ} \mathrm{C}$ for $5 \mathrm{~min}$, then heated to $200^{\circ} \mathrm{C}$ at a rate of $20^{\circ} \mathrm{C} \mathrm{min}^{-1}$ and held for $2 \mathrm{~min}$. Finally the oven was heated to $240^{\circ} \mathrm{C}$ at a rate of $20^{\circ} \mathrm{C} \mathrm{min}^{-1}$ and held for $4 \mathrm{~min}$. The total run time was $21 \mathrm{~min}$, and the MS collected data between 6 and 14 min of the run. Calibration and quantification of the compounds was performed using laboratory-prepared liquid standards, by dilution of the pure compounds into ultra-high purity methanol. The primary standards were prepared gravimetrically, the secondary and working standards by serial dilution. The analytical error as based on triplicate samples were: $<5 \%$ for Iodomethane $\left(\mathrm{CH}_{3} \mathrm{I}\right), 2$-iodopropane $\left(2-\mathrm{C}_{3} \mathrm{H}_{7} \mathrm{I}\right), 1$-iodopropane $\left(1-\mathrm{C}_{3} \mathrm{H}_{7} \mathrm{I}\right)$, chloroiodomethane $\left(\mathrm{CH}_{2} \mathrm{ClI}\right)$, bromoiodomethane $\left(\mathrm{CH}_{2} \mathrm{BrI}\right)$, $<10 \%$ for $\mathrm{CH}_{2} \mathrm{I}_{2}$, bromoform $\left(\mathrm{CHBr}_{3}\right)$, dibromomethane $\left(\mathrm{CH}_{2} \mathrm{Br}_{2}\right)$, dibromochloromethane $\left(\mathrm{CHBr}_{2} \mathrm{Cl}\right)$, and $10-15 \%$ for Iodoethane $\left(\mathrm{C}_{2} \mathrm{H}_{5} \mathrm{I}\right)$, bromochloromethane $\left(\mathrm{CH}_{2} \mathrm{BrCl}\right)$. In order to prevent the possibility of contamination of natural samples with halocarbon standards, all working standards were stored at $-20^{\circ} \mathrm{C}$ in a separate laboratory to where analyses were carried out, and handling of standards was undertaken in a fume hood. Additionally, separate glassware was used for standard runs and sample runs. Instrumental and procedural blanks were performed daily before the commencement of sample analyses, and the system was invariably found to display no contamination.

\subsection{Sea-to-air flux of halocarbons}

The sea-to-air flux of halocarbons, determined by the concentration difference between the air and seawater after correcting for solubility, was estimated for all mesocosms. Gas exchange in the mesocosms was determined by the addition of 3 times-atmospheric concentrations of $\mathrm{N}_{2} \mathrm{O}$ and the measurement of the subsequent loss rates, allowing the transfer velocity $(k)$ of $\mathrm{N}_{2} \mathrm{O}$ to be derived and enabling the estimation of the flux of other gases. For a detailed description of methods and results, see Czerny et al. (2013). Transfer velocities of halocarbons $\left(k_{\text {halo }}\right)$ were derived as follows:

$k_{\text {halo }}=k_{N 20} /\left(\mathrm{Sc}_{\text {halo }} / \mathrm{Sc}_{N 20}\right)^{0.5}$.

The Schmidt number of halocarbons ( $\mathrm{Sc}_{\text {halo }}$ ) was estimated based on experimentally determined values of molecular diffusivity for $\mathrm{CH}_{3} \mathrm{Br}$ (De Bruyn and Saltzman, 1997), using an approach described by Moore and Groszko (1999). Es- timated fluxes of halocarbons could then be calculated, using experimentally determined values of the dimensionless Henry's Law Coefficient (Moore et al., 1995), and the only reported atmospheric concentrations of halocarbons from Ny-Ålesund reported by Schall and Heumann (1993) (mean $0.46 \mathrm{pptv}$, range $<0.08-1.02 \mathrm{pptv}$ ). Fluxes were low relative to open ocean measurements due to the sheltered nature of the mesocosm environment and a minimal wind speed component (Czerny et al., 2013).

\subsection{Ancillary measurements}

All ancillary measurements described here were taken directly from the integrated water sampler from the same cast used to collect the halocarbon samples, thus providing data that is directly comparable to halocarbon concentrations.

\subsubsection{Chl $a$ and additional phytoplankton pigments}

Samples for both chl $a$ and additional phytoplankton pigments were processed as soon as possible after sampling, and in the meantime, were stored at the in situ temperature of the fjord. For chl $a 500 \mathrm{~mL}$ of seawater was filtered onto GF/F filters (Whatman), and immediately frozen and stored at $-20^{\circ} \mathrm{C}$. Chl $a$ was measured after a minimum of $24 \mathrm{~h}$ in the freezer, and extraction was performed with $10 \mathrm{~mL}$ acetone $(90 \%)$. The filter was homogenised for 4 min with $5 \mathrm{~mL}$ acetone, after which an additional $5 \mathrm{~mL}$ was added and the sample centrifuged. The supernatant was then analysed fluorometrically after the method of Welschmeyer (1994). For determination of the individual phytoplankton pigments, $2 \times 750 \mathrm{~mL}$ were filtered, which was reduced to $1 \times 750 \mathrm{~mL}$ at the onset of the bloom. The filters were immediately frozen and stored at $-80^{\circ} \mathrm{C}$ until analysis at GEOMAR. Pigments were extracted with $3 \mathrm{~mL}$ acetone and analysed using high pressure liquid chromatography (HPLC), with the addition of Canthaxanthin as an internal standard.

\subsubsection{Phytoplankton abundance and composition}

Phytoplankton composition and abundance were determined by analysis of fresh samples on a Becton Dickinson FACSort flow cytometer (FCM) equipped with a $15 \mathrm{~mW}$ laser exciting at $488 \mathrm{~nm}$ and with a standard filter set up. Samples were analysed at high flow rate $\left(\sim 150 \mu \mathrm{L} \mathrm{min}^{-1}\right)$, and specific phytoplankton groups were discriminated in bivariate scatter plots by differences in side scatter and red-orange fluorescence (Tarran et al., 2001).

\subsubsection{Total bacteria abundance}

Samples for bacterial enumeration were fixed for $30 \mathrm{~min}$ at $7^{\circ} \mathrm{C}$ with glutaraldehyde (25\%, EM-grade) at a final concentration of $0.5 \%$ before snap freezing in liquid nitrogen and storage at $-80^{\circ} \mathrm{C}$ until analysis. Bacteria were counted using an FCM according to Marie et al. (1999). Briefly, thawed 

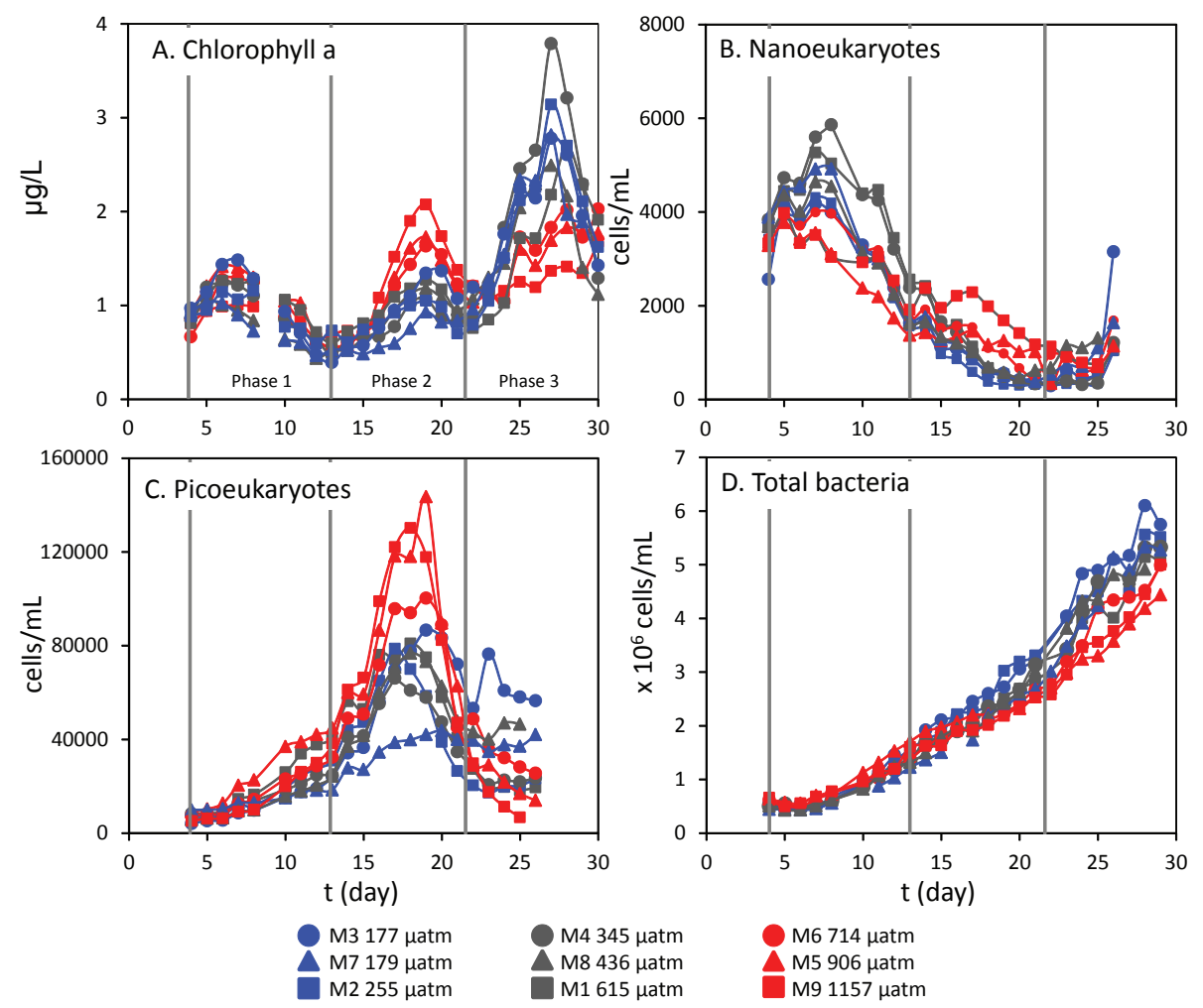

Fig. 1. Concentrations of chlorophyll $a(\mu \mathrm{g} \mathrm{L}-1)(\mathbf{A})$, nanoeukaryote $(\mathbf{B})$ and picoeukaryote abundances $(\mathbf{C})\left(\right.$ cells $\left.\mathrm{mL}^{-1}\right)$ and total bacteria (D) $\left(\times 10^{6}\right.$ cells $\left.\mathrm{mL}^{-1}\right)$ over the course of the experiment. Experimental phases are as follows: PI $t_{4}-t_{12}$, PII Days $t_{13}-t_{21}$, PIII Days $t_{22}-t_{30}$. $p \mathrm{CO}_{2}(\mu \mathrm{atm})$ shown in the legend are averages for period of halocarbon sampling $\left(t_{8}-t_{27}\right)$.

samples were diluted with Tris-EDTA buffer $(10 \mathrm{mM}$ Tris$\mathrm{HCl}$ and $1 \mathrm{mM}$ EDTA, $\mathrm{pH} 8$ ) and stained with the green fluorescent nucleic acid-specific dye SYBR-Green I (Molecular Probes, Invitrogen Inc.) at a final concentration of $1 \times 10^{-4}$ of the commercial stock, in the dark at room temperature for $15 \mathrm{~min}$. Bacteria were discriminated in bivariate scatter plots of green fluorescence versus side scatter.

\subsection{Statistical analyses}

In order to identify differences in halocarbon concentrations between mesocosms, one-way analyses of variance (ANOVA) were applied to the data. Initially, tests of normality were applied $(p<0.05=$ not normal), and if data failed to fit the assumptions of the test, linearity transformations of the data were performed (logarithmic or square root), and the ANOVA proceeded from this point. The results of ANOVA are given as follows: $F=$ ratio of mean squares, $\mathrm{df}=$ degrees of freedom, $\sigma=$ significance of $F$ test, $p=$ level of confidence. For those data which still failed to display normality following transformation, a rank-based Kruskal-Wallis test was applied ( $H=$ test statistic, $\mathrm{df}=$ degrees of freedom, $p=$ level of confidence).

Relationships between halocarbons and a range of other parameters were investigated using Pearson's correlation co- efficients $(R)$, along with the associated probability ( $F$ test, $p<0.05=$ significant). Net loss and production rates of halocarbons were derived from linear regression analyses of halocarbon concentration data as a function of time, to give the rate coefficient ( $\mathrm{pmol} \mathrm{L}^{-1} \mathrm{~d}^{-1}$ ), the coefficient of determination $\left(R^{2}\right)$, the standard error (SE) of the rate and the associated level of confidence ( $F$ test, $p<0.05=$ significant).

\section{Results}

\subsection{Halocarbon temporal dynamics}

Data for chlorophyll $a$ (chl $a$ ) and microbial plankton counts (nanoeukaryotes and picoeukaryotes, total bacteria) are shown in Fig. 1, and concentrations of halocarbons are shown in Fig. 2. The experiment was divided into three phases (PI, PII, PIII) based on the addition of nutrients and the dynamics of chl $a$ (Schulz et al., 2013). The divisions between phases are indicated on the figures as grey vertical lines (see Table 1 for a summary of timings). Mean concentrations of all halocarbons in the control mesocosms M3 and M7 were not significantly different from each other (KruskalWallis ANOVA on ranks, $p>0.05$ for all halocarbons). 

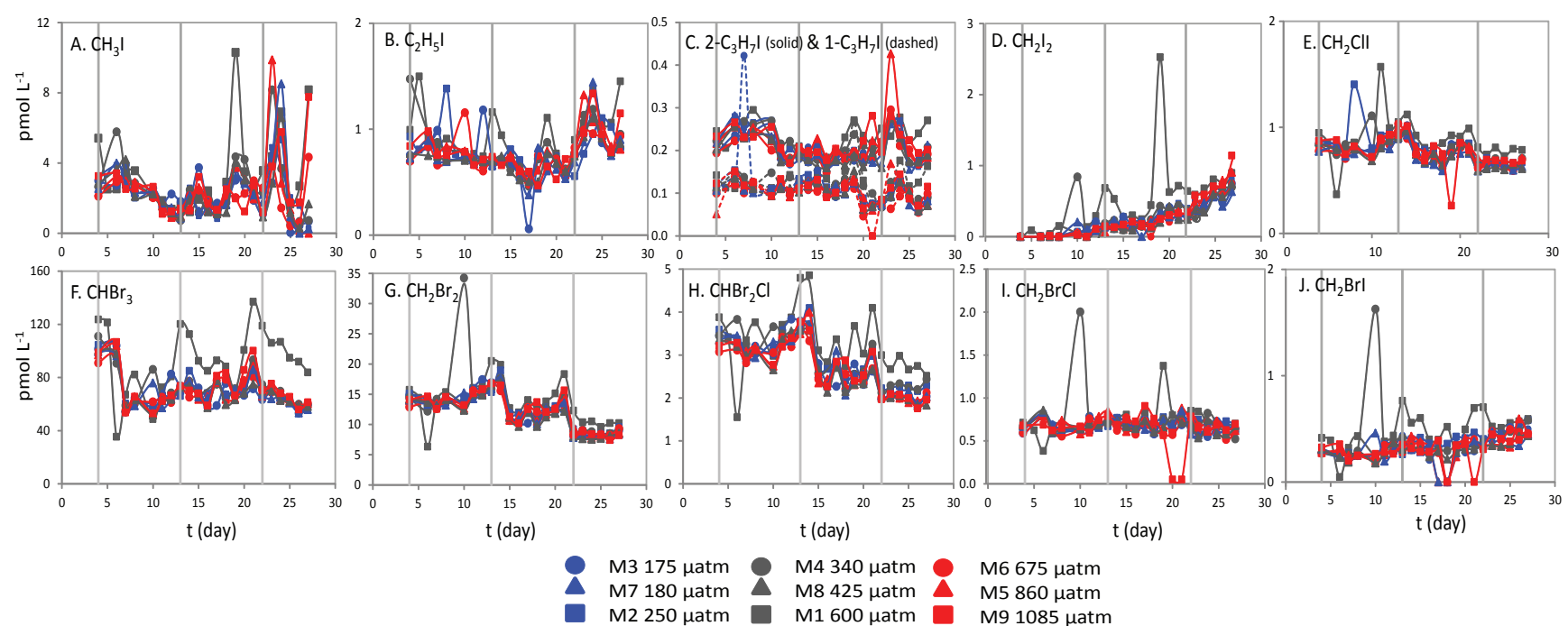

Fig. 2. Concentrations (pmol L ${ }^{-1}$ ) of I-monohalocarbons ((A) $\mathrm{CH}_{3} \mathrm{I},(\mathbf{B}) \mathrm{C}_{2} \mathrm{H}_{5} \mathrm{I}$ and (C) $2-\mathrm{C}_{3} \mathrm{H}_{7} \mathrm{I}$ (solid) and 1- $\mathrm{C}_{3} \mathrm{H}_{7} \mathrm{I}$ (dashed)), Ipolyhalocarbons $\left((\mathbf{D}) \mathrm{CH}_{2} \mathrm{I}_{2}\right.$, (E) $\left.\mathrm{CH}_{2} \mathrm{ClI}\right)$ and Br-polyhalocarbons $(\mathbf{F}) \mathrm{CHBr}_{3}$, (G) $\left.\mathrm{CH}_{2} \mathrm{Br},(\mathbf{H}) \mathrm{CHBr}_{2} \mathrm{Cl}, \mathrm{I} . \mathrm{CH}{ }_{2} \mathrm{BrCl}(\mathbf{J}) \mathrm{CH} 2 \mathrm{BrI}\right)$. Grey lines indicate phases of the experiment: PI $t_{4}-t_{12}$, PII Days $t_{13}-t_{21}$, PIII Days $t_{22}-t_{30} \cdot p \mathrm{CO}_{2}(\mu \mathrm{atm})$ shown in the legend are averages for period $t_{8}-t_{27}$.

\subsubsection{Iodocarbons}

Concentrations of $\mathrm{CH}_{3} \mathrm{I}$ and $\mathrm{C}_{2} \mathrm{H}_{5} \mathrm{I}$ (Fig. 2a and b) showed some variability over the course of the experiment, falling gradually during PI, in parallel to chl $a$ concentrations and nanophytoplankton abundances. Peaks occurred following nutrient addition and in parallel with the chl $a$ peak on $t_{19}$ in PII, and during the rapid rise in chl $a$ observed during PIII which was attributed to increases in diatoms, prasinophytes, and to a certain extent haptophytes (Schulz et al., 2013). Concentrations ranged from 0.04 to $10.29 \mathrm{pmol} \mathrm{L}^{-1}$ and 0.06 to $3.32 \mathrm{pmol} \mathrm{L}^{-1}$, for $\mathrm{CH}_{3} \mathrm{I}$ and $\mathrm{C}_{2} \mathrm{H}_{5} \mathrm{I}$ respectively. Concentrations of the propyl iodides (Fig. 2c) were less variable, with concentrations varying by less than $0.5 \mathrm{pmol} \mathrm{L}^{-1}$, and overall mean concentrations of $0.21 \mathrm{pmol} \mathrm{L}^{-1}\left(2-\mathrm{C}_{3} \mathrm{H}_{7} \mathrm{I}\right)$ and $0.12 \mathrm{pmol} \mathrm{L}^{-1}\left(1-\mathrm{C}_{3} \mathrm{H}_{7} \mathrm{I}\right)$. However, concentrations did show some increase that coincided with the final chl $a$ maximum in PIII. 2- $\mathrm{C}_{3} \mathrm{H}_{7} \mathrm{I}$ was consistently higher than $1-\mathrm{C}_{3} \mathrm{H}_{7} \mathrm{I}$ by $\sim 0.1 \mathrm{pmol} \mathrm{L}^{-1}$. For all of the above and for the experiment as a whole, no significant differences in mean concentrations were detected between mesocosms and no apparent effect of $p \mathrm{CO}_{2}$ were observed (KruskalWallis ANOVA on ranks ( $\mathrm{df}=8): \mathrm{CH}_{3} \mathrm{I} H=6.06, p=0.64$; $\mathrm{C}_{2} \mathrm{H}_{5} \mathrm{I} H=15.03, p=0.06 ; 2-\mathrm{C}_{3} \mathrm{H}_{7} \mathrm{I} H=11.73, p=0.11$; $1-\mathrm{C}_{3} \mathrm{H}_{7} \mathrm{I} H=10.22, p=0.18$ ).

In contrast to all other halocarbons, $\mathrm{CH}_{2} \mathrm{I}_{2}$ concentrations (Fig. 2d) gradually increased over the course of the experiment, from below detection limit (D.L. $<10 \mathrm{fmol} \mathrm{L}^{-1}$ ) on $t_{4}$, reaching $0.5-1.0 \mathrm{pmol} \mathrm{L}^{-1}$ by $t_{27}$. M1 displayed significantly higher concentrations over almost the entire duration of the experiment, with a maximum and seemingly anomalous value of $2.5 \mathrm{pmol} \mathrm{L}^{-1}$ on $t_{19}$ (ANOVA
$F=2.52, \mathrm{df}=8, \sigma=0.014, p<0.05)$. In PIII concentrations showed some response to $p \mathrm{CO}_{2}$ treatment, with significantly higher mean $\mathrm{CH}_{2} \mathrm{I}_{2}$ concentrations as a function of mean $p \mathrm{CO}_{2}\left(R^{2}=0.451, n=9, p<0.05\right) . \mathrm{CH}_{2} \mathrm{ClI}$ concentrations (Fig. 2e) were generally stable $\left(0.5-1.0 \mathrm{pmol} \mathrm{L}^{-1}\right)$, with the exception of a small rise to a peak on $t_{14}$, just prior to the nutrient-induced increase in chl $a$. Finally, concentrations of $\mathrm{CH}_{2} \mathrm{ClI}$ did not respond significantly to $p \mathrm{CO}_{2}$ treatment, although concentrations in $\mathrm{M} 1$ were significantly higher than M6, M7 and M8 (Kruskal-Wallis ANOVA on ranks $H=22.19$, $\mathrm{df}=8, p=0.005$, pairwise comparison with Dunn's method - all $p<0.05$ ).

\subsubsection{Bromocarbons}

The temporal development of concentrations of $\mathrm{CHBr}_{3}$, $\mathrm{CH}_{2} \mathrm{Br}_{2}$ and $\mathrm{CHBr}_{2} \mathrm{Cl}$ (Fig. 2f-h) showed a high degree of similarity, with a gradual rise from $t_{6}$, a sharp drop at the start of PII followed by a period of recovery during the nutrientinduced chl $a$ peak, and falling or unchanging concentrations during PIII. For the entire experiment the concentrations of $\mathrm{CHBr}_{3}>\mathrm{CH}_{2} \mathrm{Br}_{2}>\mathrm{CHBr}_{2} \mathrm{Cl}$ with mean concentrations for all mesocosms of $72.8 \mathrm{pmol} \mathrm{L}^{-1} 12.4 \mathrm{pmol} \mathrm{L}^{-1}$ and $2.8 \mathrm{pmol} \mathrm{L}^{-1}$, respectively. Similarly to $\mathrm{CH}_{2} \mathrm{I}_{2}$, concentrations of $\mathrm{CHBr}_{3}, \mathrm{CH}_{2} \mathrm{Br}_{2}$ and $\mathrm{CHBr}_{2} \mathrm{Cl}$ were almost consistently higher in $\mathrm{M} 1$ (significantly higher for $\mathrm{CHBr}_{3}$ KruskalWallis ANOVA on ranks $H=27.258, \mathrm{df}=8, p<0.001$ ), although they followed similar temporal trends to the other mesocosms. Concentrations of $\mathrm{CH}_{2} \mathrm{BrCl}$ (Fig. 2i) were low $\left(<0.1 \mathrm{pmol} \mathrm{L}^{-1}\right)$ and stable, with the exception of a small number of anomalous data points in PI and PII. $\mathrm{CH}_{2} \mathrm{BrI}$ showed little variability as the experiment 
Table 2. Seawater concentrations of halocarbons in Kongsfjorden reported by Schall and Heumann (1993), Hughes (2004) and measured during this study.

\begin{tabular}{|c|c|c|c|c|c|c|c|c|}
\hline \multirow[t]{2}{*}{$\mathrm{pmol} \mathrm{L}^{-1}$} & \multicolumn{2}{|c|}{ Schall and Heumann (1993) } & \multicolumn{2}{|c|}{ Hughes (2004) } & \multicolumn{2}{|c|}{ This study (fjord) } & \multicolumn{2}{|c|}{ This study (mesocosms) } \\
\hline & mean & range & mean & range & mean & range & mean & range \\
\hline $\mathrm{CH}_{3} \mathrm{I}$ & 2.3 & $0.6-5.4$ & - & $0.5-1.6$ & 4.9 & $2.5-18.4$ & 2.6 & $0.04-10.3$ \\
\hline $\mathrm{C}_{2} \mathrm{H}_{5} \mathrm{I}$ & - & - & - & $0.05-0.4$ & 1.3 & $0.9-2.9$ & 0.9 & $0.1-3.3$ \\
\hline $2-\mathrm{C}_{3} \mathrm{H}_{7} \mathrm{I}$ & 2.6 & $0.4-5.5$ & - & - & 0.4 & $0.3-0.7$ & 0.2 & $0.2-0.4$ \\
\hline $1-\mathrm{C}_{3} \mathrm{H}_{7} \mathrm{I}$ & 2.5 & $0.4-9.4$ & - & - & 0.3 & $0.1-0.3$ & 0.1 & $0.06-0.4$ \\
\hline $\mathrm{CH}_{2} \mathrm{I}_{2}$ & 6.2 & $0.9-12.7$ & - & - & 0.9 & $0.0-2.7$ & 0.2 & $0.01-2.5$ \\
\hline $\mathrm{CH}_{2} \mathrm{ClI}$ & 1.8 & $0.9-2.6$ & - & $<$ D.L. & 1.4 & $0.7-2.5$ & 0.8 & $0.3-1.6$ \\
\hline $\mathrm{CHBr}_{3}$ & 77.0 & $34.4-157.7$ & - & - & 207.0 & $122.9-358.1$ & 84.0 & $35.3-151.5$ \\
\hline $\mathrm{CH}_{2} \mathrm{Br}_{2}$ & 15.8 & 7.2-30.1 & - & - & 23.9 & $14.0-44.6$ & 12.7 & $6.3-33.3$ \\
\hline $\mathrm{CH}_{2} \mathrm{BrCl}$ & 1.5 & $0.5-3.6$ & - & - & 1.0 & $0.5-2.7$ & 0.7 & $0.1-2.0$ \\
\hline $\mathrm{CHBr}_{2} \mathrm{Cl}$ & 5.1 & $2.5-9.5$ & - & - & 6.5 & $3.7-11.3$ & 2.9 & $1.6-4.7$ \\
\hline $\mathrm{CH}_{2} \mathrm{BrI}$ & - & - & - & - & 1.3 & $0.3-3.1$ & 0.3 & $0.0-1.6$ \\
\hline
\end{tabular}

progressed (overall mean $=0.35 \mathrm{pmol} \mathrm{L}^{-1}$ ), with the exception of some anomalous spikes in concentration during PI and II, and little response to nutrient-addition or phytoplankton growth (Fig. 2j). No significant responses to $p \mathrm{CO}_{2}$ were detected (Kruskall-Wallis ANOVA on ranks $(\mathrm{df}=8): \mathrm{CHBr}_{3}$ $H=3.94, p=0.86 ; \mathrm{CH}_{2} \mathrm{Br}_{2} H=2.22, p=0.95 ; \mathrm{CH}_{2} \mathrm{BrCl}$ $H=8.94, p=0.35 ; \mathrm{CHBr}_{2} \mathrm{Cl} H=4.84, p=0.68 ; \mathrm{CH}_{2} \mathrm{BrI}$ $H=10.67, p=0.16)$.

\subsection{Halocarbons and biological parameters}

In order to identify possible sources or sinks in the mesocosms, mean concentrations of halocarbons were compared with a number of biological parameters ( $\operatorname{chl} a$, nanoeukaryote and picoeukaryote abundance, and total bacteria abundance). To simplify these analyses and to give an overview of general trends, halocarbons concentrations were averaged across all mesocosms and assigned to three groups based on their common biological production pathways (Manley, 2002): (1) I-monohalocarbons $\left(\mathrm{CH}_{3} \mathrm{I}, \mathrm{C}_{2} \mathrm{H}_{5} \mathrm{I}, 2-\right.$ $\mathrm{C}_{3} \mathrm{H}_{7} \mathrm{I}, 1-\mathrm{C}_{3} \mathrm{H}_{7} \mathrm{I}$ ), potentially formed via methyl transferase activity, (2) I-polyhalocarbons $\left(\mathrm{CH}_{2} \mathrm{I}_{2}, \mathrm{CH}_{2} \mathrm{ClI}\right)$, potentially formed via iodoperoxidase activity, (3) Br-polyhalocarbons $\left(\mathrm{CHBr}_{3}, \mathrm{CH}_{2} \mathrm{Br}_{2}, \mathrm{CH}_{2} \mathrm{BrCl}, \mathrm{CHBr}_{2} \mathrm{Cl}, \mathrm{CH}_{2} \mathrm{BrI}\right)$, potentially formed via bromoperoxidase activity (compare Fig. 3). Imonohalocarbons showed the strongest correlations with biological parameters during PI (Fig. 3a-d). Significant positive correlations were identified with both chl $a$ and nanophytoplankton (Fig. 3a and c), whilst significant negative correlations were observed with picoeukaryotes and total bacteria (Fig. 3b and d). No significant correlations were observed during PII and PIII. PI also revealed a number of strong relationships between I-polyhalocarbons and biological parameters (Fig. 3e-h), although the trends were consistently of an opposite nature to I-monohalocarbons. Significant negative correlations were identified with both chl $a$ concentrations and nanoeukaryote abundance (Fig. 3e and g), and signifi- cant positive correlations with picoeukaryotes and total bacteria (Fig. $5 \mathrm{f}$ and h). No significant correlations were seen in PII. In PIII, significant positive correlations were found with chl $a$ and total bacteria, and significant negative correlations were found with picoeukaryotes. No significant correlations were identified for Br-polyhalocarbons during PI and PII (Fig. 3i-1). During PIII, chl $a$ and total bacteria gave significant negative correlations (Fig. $3 i$ and 1), whilst picoeukaryotes showed a significant positive relationship (Fig. 3j).

\subsection{Halocarbons and $p \mathrm{CO}_{2}$}

In order to determine the effect of $p \mathrm{CO}_{2}$ on concentrations of halocarbons, the strength of the correlation between mean concentrations and $p \mathrm{CO}_{2}$ for each experimental phase was examined. A significant increase in both mean and cumulative concentrations of $\mathrm{CH}_{2} \mathrm{I}_{2}$ under increasing $\mathrm{CO}_{2}$ was seen in PIII ( $R=0.67, F=5.75, p<0.05)$ (Fig. 4a). No further relationships were identified between the standing stocks of halocarbons and $p \mathrm{CO}_{2}$.

\section{Discussion}

Absolute concentrations of halocarbons measured in the mesocosms were comparable to two earlier studies that reported halocarbons from Kongsfjorden, and the data is summarised in Table 2 (Hughes, 2004; Schall and Heumann, 1993). Schall and Heumann (1993) (hereafter SH93) analysed seawater samples collected $1 \mathrm{~km}$ from the shore during September - a comparable location to the mesocosms, during a similar season. Mean concentrations of $\mathrm{CH}_{3} \mathrm{I}$ show strong similarity, although a greater range was observed in the mesocosms, perhaps a result of the nutrient-induced phytoplankton growth. Concentrations of the remaining compounds were generally lower in the mesocosms than those measured by SH93. Similarly, mean concentrations were consistently higher in the fjord compared to the mesocosms 

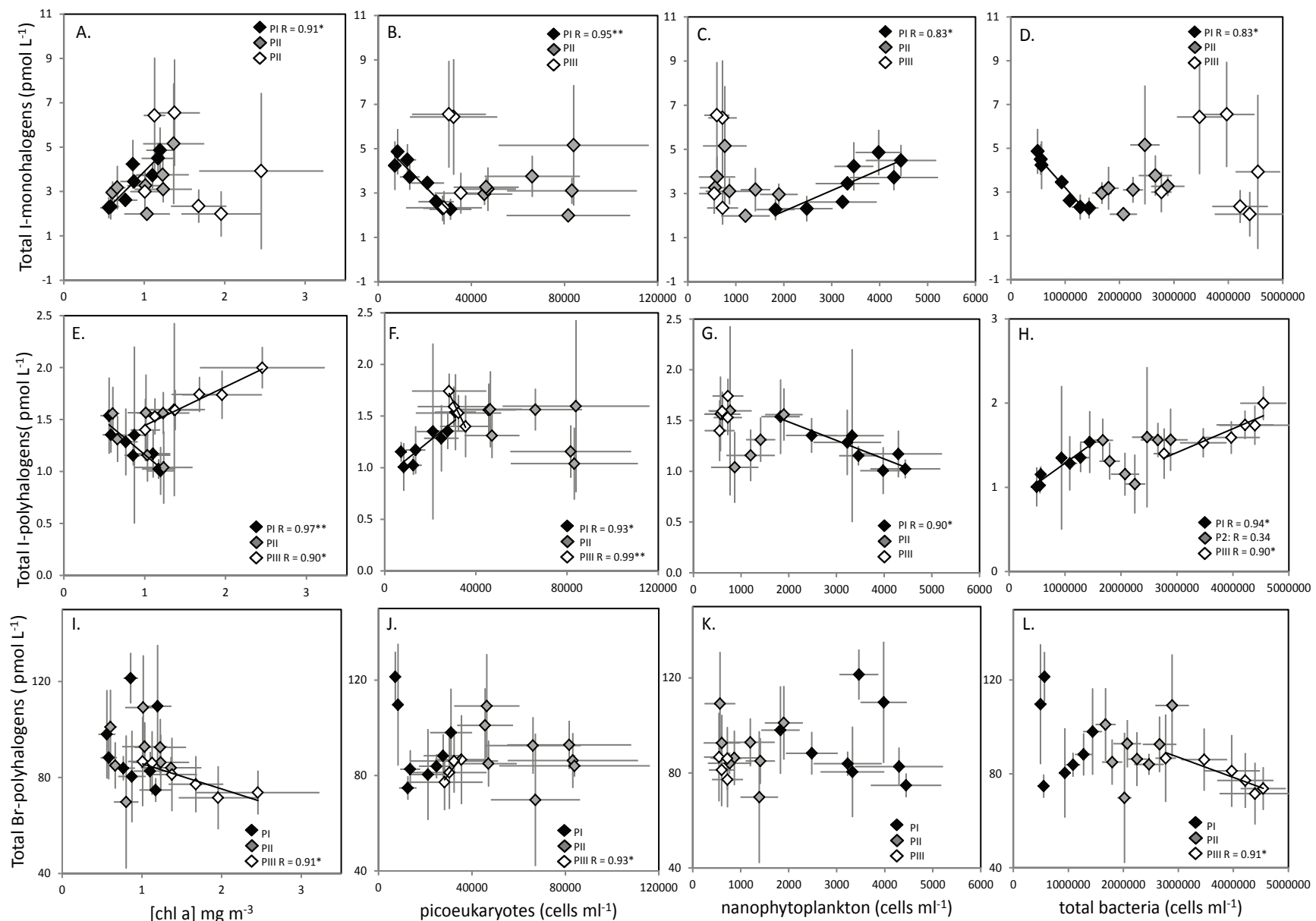

Fig. 3. Relationships between mean halocarbon concentration (pmol L ${ }^{-1}$ ) and biological parameters ( $L$ to $R$, chl $a$, picoeukaryotes, nanophytoplankton, bacterial abundance). (A-D) total I-monohalocarbons (sum of $\mathrm{CH}_{3} \mathrm{I}, \mathrm{C}_{2} \mathrm{H}_{5} \mathrm{I}, 2-\mathrm{C}_{3} \mathrm{H}_{7} \mathrm{I}, 1-\mathrm{C}_{3} \mathrm{H}_{7} \mathrm{I}$ ), (E-H) total I-polyhalocarbons (sum of $\mathrm{CH}_{2} \mathrm{I}_{2}$ and $\mathrm{CH}_{2} \mathrm{ClI}$ ), (I-L) total Br-polyhalocarbons (sum of $\mathrm{CHBr}_{3}, \mathrm{CH}_{2} \mathrm{Br}_{2}, \mathrm{CHBr}_{2} \mathrm{Cl}_{2} \mathrm{CH}_{2} \mathrm{BrCl}_{1} \mathrm{CH} \mathrm{CrI}_{2}$ ). $\mathrm{PI}$ (black diamonds), PII (grey diamonds) and PIII (open diamonds). Error bars indicate range of all data from all mesocosms. Asterisks denote significance level of correlation $(R):^{*}=p<0.05,{ }^{* *}=p<0.001$.

during this study, with the greatest difference in mean concentrations seen for $\mathrm{CH}_{2} \mathrm{I}_{2}(78 \%)$ and the least difference for $\mathrm{CH}_{2} \mathrm{BrCl}(28 \%)$. Whilst differences in halocarbon concentrations between the fjord and mesocosms may be a product of the temporal progression of their respective microbial communities, variations in light regimes and exclusion of benthic processes may have contributed to the variations. For instance, almost minimal ultraviolet (UV) light $(<380 \mathrm{~nm})$ was transmitted through the mesocosm foil (Matthias Fischer, personal communication, 2012), and furthermore, potential macroalgal sources of halocarbons were excluded from the mesocosms.

For a number of halocarbons, anomalous spikes in concentrations were observed on a small number of occasions (Fig. 2). Excluding the likelihood of contamination of the analytical system (see Sect. 2.3), it is possible that these elevated concentrations were caused by aggregates of biogenic material, known to be "hotspots" of halocarbon production, incidentally included in particular samples (Hughes et al., 2008).

\subsection{Processes controlling halocarbon concentrations in the mesocosms}

During this experiment, 11 individual halocarbon compounds were quantified, along with numerous other biological and chemical parameters. Attempts to discuss each halocarbon individually would lead to an extensive and complicated discussion. Therefore in order to rationalise the following section, the discussion will focus on one halocarbon from each of the groups detailed in Sect. 3.2, on the assumption that the remaining halocarbons of each group are subject to similar production and removal mechanisms: (1) $\mathrm{CH}_{3} \mathrm{I}$ (I-monohalogenated), (2) $\mathrm{CH}_{2} \mathrm{I}_{2}$ (I-polyhalogenated) and (3) $\mathrm{CHBr}_{3}$ (Br-polyhalogenated). These halocarbons are either the dominant gas from each group in terms of 
Table 3. Correlation coefficients $(R)$ for $\mathrm{CH}_{3} \mathrm{I}\left(\mathrm{pmol} \mathrm{L}^{-1}\right)$ and selected biological parameters during $\mathrm{PI}\left(t_{4}-t_{12}\right)$. Asterisks indicate associated probability: ${ }^{*} p<0.05,{ }^{* *} p<0.01$.

\begin{tabular}{lrrrrrrrrrrr}
\hline \multicolumn{10}{c}{$\mathrm{CH}_{3} \mathrm{I}$} \\
\hline & $\mathrm{n}$ & $\mathrm{M} 1$ & $\mathrm{M} 2$ & $\mathrm{M} 3$ & $\mathrm{M} 4$ & M5 & M6 & M7 & M8 & M9 & mean \\
\hline Chlorophyll $a$ & 10 & $0.87^{*}$ & 0.70 & $0.74^{*}$ & $0.88^{*}$ & $0.94^{* *}$ & $0.92^{*}$ & $0.90^{*}$ & $0.90^{*}$ & 0.66 & $0.93^{* *}$ \\
Picoeukaryotes & 10 & $-0.76^{*}$ & -0.60 & $-0.71^{*}$ & $-0.84^{* *}$ & $-0.82^{*}$ & $-0.84^{* *}$ & $-0.86^{* *}$ & $-0.83^{*}$ & $-0.88^{* *}$ & $-0.89^{*}$ \\
Nanoeukaryotes & 10 & $0.83^{*}$ & $0.75^{*}$ & 0.59 & $0.83^{*}$ & $0.94^{* *}$ & $0.87^{* *}$ & $0.81^{*}$ & $0.83^{*}$ & $0.67^{*}$ & $0.85^{*}$ \\
Total bacteria & 9 & $-0.85^{*}$ & $-0.95^{* *}$ & $-0.75^{*}$ & $-0.85^{*}$ & $-0.94^{* *}$ & $-0.90^{*}$ & $-0.91^{*}$ & $-0.94^{* *}$ & $-0.85^{*}$ & $-0.92^{*}$ \\
Fucoxanthin & 6 & $0.99^{* *}$ & $0.91^{*}$ & 0.82 & 0.73 & $0.89^{*}$ & $0.86^{*}$ & 0.69 & 0.73 & 0.25 & $0.81^{*}$ \\
Peridinin & 6 & 0.40 & $0.82^{*}$ & 0.53 & $0.90^{*}$ & 0.75 & 0.68 & 0.55 & $0.81^{*}$ & 0.38 & $0.89^{*}$ \\
\hline
\end{tabular}

concentrations and/or are the most important in terms of their influence on atmospheric chemistry.

\subsubsection{Iodomethane $\left(\mathrm{CH}_{3} \mathrm{I}\right)$}

The temporal dynamics of $\mathrm{CH}_{3} \mathrm{I}$ were characterised by periods of both net loss and net production, resulting in concentrations that ranged between below D.L. $\left(<1 \mathrm{pmol} \mathrm{L}^{-1}\right)$ and $\sim 10 \mathrm{pmol} \mathrm{L}^{-1}$, suggesting active turnover of this compound within the mesocosms (Fig. 2a). Numerous strong relationships to biological parameters were identified, predominantly during PI (Table 3). $\mathrm{CH}_{3} \mathrm{I}$ concentrations gave significant positive correlations with chl $a$, nanoeukaryotes, and phytoplankton pigment concentrations (fucoxanthin, chl C1/C2, peridinin), whilst $\mathrm{CH}_{3} \mathrm{I}$ was inversely correlated with picoeukaryotes and total bacterial abundances. Yet, despite the apparent close association with biological activity and the strong $\mathrm{CO}_{2}$ effect on a number of biological parameters (Brussaard et al., 2013; Schulz et al., 2013), no consistent or prolonged response to $p \mathrm{CO}_{2}$ was seen in the concentrations of $\mathrm{CH}_{3} \mathrm{I}$.

In order to speculate on the lack of response of $\mathrm{CH}_{3} \mathrm{I}$ concentrations to $\mathrm{CO}_{2}$, the processes controlling the production and removal of $\mathrm{CH}_{3} \mathrm{I}$ in seawater must first be explained. Direct biological production is thought to occur via methyl transferase enzyme activity by both phytoplankton and bacteria (Amachi et al., 2001). The strong correlations with a number of biological parameters in the mesocosms provide evidence for this source. In addition, production is possible from the breakdown of higher molecular weight iodine-containing organic matter (Fenical, 1982) and through photochemical reactions between organic matter and light (Richter and Wallace, 2004), both of which may have made some contribution to the production of $\mathrm{CH}_{3} \mathrm{I}$ in the mesocosm. In terms of removal, $\mathrm{CH}_{3} \mathrm{I}$ undergoes nucleophilic substitution and hydrolysis in seawater (Elliott and Rowland, 1993), although the rates of reaction are minimal at the water temperatures experienced during the experiment $\left(0.1-0.3 \% \mathrm{~d}^{-1}\right)$ so it is likely that these processes made a negligible contribution to the overall loss of $\mathrm{CH}_{3} \mathrm{I}$. It is also probable that some $\mathrm{CH}_{3} \mathrm{I}$ undergoes consumption by bacteria, and results of laboratory incubations with ${ }^{13} \mathrm{C}$-labelled $\mathrm{CH}_{3} \mathrm{I}$ have provided evidence of significant "biological" loss rates (Frances Hopkins, personal communcation, 2012). Seawater $\mathrm{CH}_{3} \mathrm{I}$ is also lost via the sea-to-air flux, and this comprised a relatively small component of the total loss during this experiment. For example, during PI the mean sea-to-air flux of $\mathrm{CH}_{3} \mathrm{I}$ was estimated at $73.1 \mathrm{pmol} \mathrm{m}^{-2} \mathrm{~d}^{-1}$. Therefore, when scaled to allow comparison with the total net loss, assuming a $12 \mathrm{~m}$ deep mixed water column, this flux represents $8 \mathrm{fmol} \mathrm{L}^{-1} \mathrm{~d}^{-1}$, equivalent to $<4 \%$ of the total $\left(0.25 \mathrm{pmol} \mathrm{L}^{-1} \mathrm{~d}^{-1}\right)$.

Clearly, the controls on seawater concentrations of $\mathrm{CH}_{3} \mathrm{I}$ are varied and complex. Furthermore, halocarbons occur at such low levels in seawater (picomolar) that distinguishing the underlying processes from bulk measurements is very difficult. The strongest relationships between $\mathrm{CH}_{3} \mathrm{I}$ and biological activity were seen during PI, a period when the biological response to $p \mathrm{CO}_{2}$ was minimal (Schulz et al., 2013). Over the course of PII and PIII, the coupling between $\mathrm{CH}_{3} \mathrm{I}$ concentrations and biological parameters such as chl $a$ lessened, suggesting a decrease in the importance of direct biological production and a rise in the importance of other production processes. Consequently, a $\mathrm{CO}_{2}$ effect on $\mathrm{CH}_{3} \mathrm{I}$ of the kind seen on biological parameters during PII and PIII was not detectable.

\subsubsection{Diiodomethane $\left(\mathrm{CH}_{2} \mathrm{I}_{2}\right)$}

The main loss pathway for $\mathrm{CH}_{2} \mathrm{I}_{2}$ in seawater is photolysis at near-ultraviolet (UV) wavelengths (300-350 nm) (Martino et al., 2006). However, it is likely that this process was negligible in the mesocosms due to lack of UV transmission through the foil (Matthias Fischer, personal communication, 2012). The lack of photolysis may have facilitated the gradual increase in $\mathrm{CH}_{2} \mathrm{I}_{2}$ concentrations over the course of the experiment (Fig. 2d). Furthermore, $\mathrm{CH}_{2} \mathrm{I}_{2}$ was the only halocarbon to show a significant positive response to $p \mathrm{CO}_{2}$ chiefly during PIII (Fig. 4a). The temporal data underwent linear regression analysis to reveal significant net production rates $\left(\mathrm{pmol} \mathrm{L}^{-1} \mathrm{~d}^{-1}\right)$ in all mesocosms (Table 4). Rates ranged from $0.027 \mathrm{pmol} \mathrm{L}^{-1} \mathrm{~d}^{-1}$ in M3 to $0.039 \mathrm{pmol} \mathrm{L}^{-1} \mathrm{~d}^{-1}$ in M9. Next, net production rates 

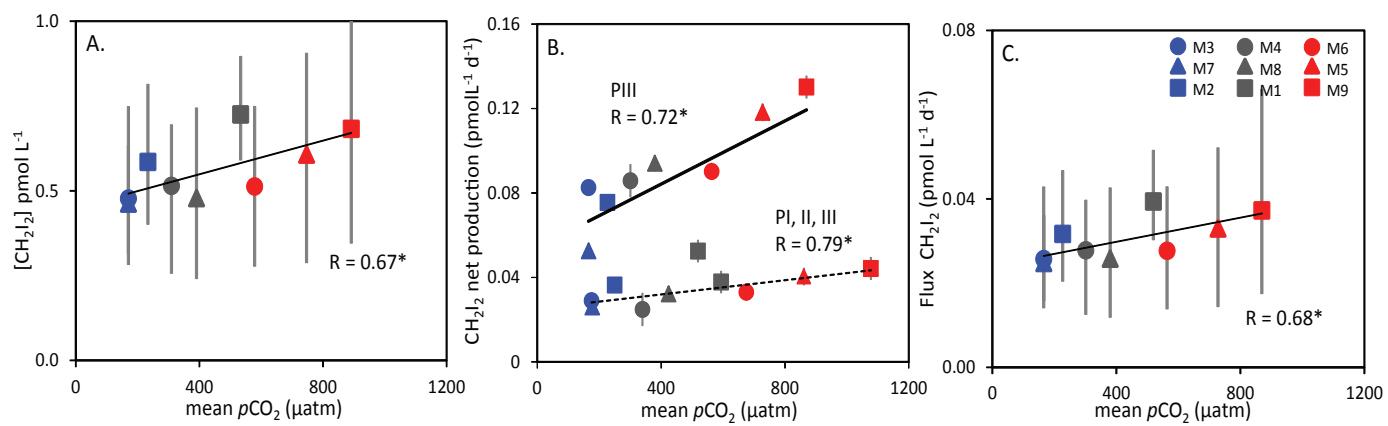

Fig. 4. Relationships in PIII between (A) mean $\mathrm{CH}_{2} \mathrm{I}_{2}$ concentration (pmol d ${ }^{-1}$ ) and mean $p \mathrm{CO}_{2}(\mu a t m)$, (B) the mean net production rate of $\mathrm{CH}_{2} \mathrm{I}_{2}\left(\mathrm{pmol} \mathrm{L}-1 \mathrm{~d}^{-1}\right.$ ) and mean $p \mathrm{CO}_{2}$ ( $\mu$ atm) for PI-PIII (dashed line) and PIII only (solid line), and (C) the mean sea-to-air flux of $\mathrm{CH}_{2} \mathrm{I}_{2}\left(\mathrm{pmol} \mathrm{m}^{-2} \mathrm{~d}^{-1}\right)$, all for Phase III $\left(t_{22}-t_{27}\right)$. Asterisks denote significance level of correlation $(R){ }^{*}=p<0.05,{ }^{* *}=p<0.01$. Error bars show range of data.

Table 4. $\mathrm{CH}_{2} \mathrm{I}_{2}$ net production rates and coefficient of determination $\left(R^{2}\right)$ of the linear regression for period $t_{4}-t_{27}$. Asterisks indicate associated probability: ${ }^{* *}=p<0.01$.

\begin{tabular}{ccc}
\hline & $\begin{array}{c}\mathrm{CH}_{2} \mathrm{I}_{2} \text { net production rate } \\
\left(\mathrm{pmol} \mathrm{L}^{-1} \mathrm{~d}^{-1}\right)( \pm \mathrm{SE})\end{array}$ & $R^{2}$ \\
\hline M1 & $0.037( \pm 0.004)$ & $0.82^{* *}$ \\
M2 & $0.033( \pm 0.003)$ & $0.89^{* *}$ \\
M3 & $0.027( \pm 0.003)$ & $0.83^{* *}$ \\
M4 & $0.030( \pm 0.003)$ & $0.84^{* *}$ \\
M5 & $0.035( \pm 0.004)$ & $0.83^{* *}$ \\
M6 & $0.029( \pm 0.003)$ & $0.84^{* *}$ \\
M7 & $0.025( \pm 0.002)$ & $0.87^{* *}$ \\
M8 & $0.028( \pm 0.003)$ & $0.78^{* *}$ \\
M9 & $0.039( \pm 0.005)$ & $0.77^{* *}$ \\
\hline
\end{tabular}

for each mesocosm underwent correlative analysis with the associated mean $p \mathrm{CO}_{2}$, revealing significant positive correlations for both the whole experiment (dashed line symbols, $R=0.79, p<0.05$ ) and for PIII (solid line, $R=0.72$, $p<0.05$ ) (Fig. 4b).

Furthermore, concentrations of $\mathrm{CH}_{2} \mathrm{I}_{2}$ were strongly, and often significantly, correlated with a number of biological parameters. Shown in Table 5, $\mathrm{CH}_{2} \mathrm{I}_{2}$ was closely positively correlated with both chl $a$ and total bacteria for the whole experiment, whilst close positive relationships with the phytoplankton pigments fucoxanthin and peridinin were observed during PIII. Taking into account the relationship between $\mathrm{CH}_{2} \mathrm{I}_{2}$ and biological parameters, the possible reasons for an increase in net production of $\mathrm{CH}_{2} \mathrm{I}_{2}$ in response to increasing $p \mathrm{CO}_{2}$ will be explored in the following section.

The production of I-polyhalocarbons $\left(\mathrm{CH}_{2} \mathrm{I}_{2}, \mathrm{CH}_{2} \mathrm{CII}\right)$ can be the result of iodoperoxidase enzyme activity that catalyses the destruction of $\mathrm{H}_{2} \mathrm{O}_{2}$ and stimulates iodination reactions to form polyhalogenated products (Moore et al., 1996; Leblanc et al., 2006). The exact reason for algal-mediated production of volatile halocarbons is not fully understood, although theories exist as to the function of this process (Manley, 2002; Leblanc et al., 2006). As the consequence of haloperoxidase activity is to reduce $\mathrm{H}_{2} \mathrm{O}_{2}$ concentrations, it provides an antioxidant function. Therefore the up-regulation of $\mathrm{CH}_{2} \mathrm{I}_{2}$ production seen here in response to altered seawater carbonate chemistry, or indeed some other unidentified stressor, may be indicative of an adaptive response due to perturbed cell physiology amongst the plankton community.

The strong significant negative correlations between $\mathrm{CH}_{2} \mathrm{I}_{2}$ and total bacterial abundances over the duration of the experiment are intriguing and suggest some bacterial involvement in the turnover of this compound. There are no reported studies of the biological consumption of $\mathrm{CH}_{2} \mathrm{I}_{2}$. However, there is direct evidence for bacterial consumption of $\mathrm{CH}_{2} \mathrm{Br}_{2}$ (Goodwin et al., 1997, 1998), so this process cannot be ruled out for $\mathrm{CH}_{2} \mathrm{I}_{2}$. A small number of studies have investigated the involvement of bacteria in the production of Ipolyhalocarbons, yielding somewhat limited and speculative information. Strains of iodine-oxidising bacteria (IOB) have been isolated from seawater, implicating species closely related to the marine bacterium Roseovarius tolerans (aerobic bacteriochlorophyll $a$-producer) (Fuse et al., 2003; Amachi, 2008). During laboratory enrichment incubations, IOB directly produced free iodine $\left(\mathrm{I}_{2}\right)$ which led to the production of abundant organic iodine species, specifically $\mathrm{CH}_{2} \mathrm{I}_{2}$, $\mathrm{CH}_{2} \mathrm{ClI}$ and $\mathrm{CHI}_{3}$ via an extracellular oxidase enzyme. $\mathrm{Al}-$ though enrichment incubations are far removed from processes occurring in natural seawater, Amachi (2008) speculates that IOB may be widely distributed in the marine environment, raising the possibility that given the right conditions, IOB could significantly contribute to the production of $\mathrm{CH}_{2} \mathrm{I}_{2}$ in the marine environment. The significant negative correlations between bacterial abundance and $\mathrm{CH}_{2} \mathrm{I}_{2}$ concentration as well as increasing ratios of $\mathrm{CH}_{2} \mathrm{I}_{2}$ per bacteria cell with increasing $p \mathrm{CO}_{2}$ suggest either: (1) an increase in bacterial production of $\mathrm{CH}_{2} \mathrm{I}_{2}$, or (2) a decrease in bacterial consumption of $\mathrm{CH}_{2} \mathrm{I}_{2}$, in response to increasing $p \mathrm{CO}_{2}$. 
Table 5. Correlation coefficients $(R)$ for relationship between $\mathrm{CH}_{2} \mathrm{I}_{2}\left(\right.$ pmol L ${ }^{-1}$ ) and chlorophyll $a$, total bacterial abundance, and phytoplankton pigments(fucoxanthin and peridinin). Asterisks indicate associated probability: ${ }^{*} p<0.05,{ }^{* *} p<0.01$.

\begin{tabular}{lrrrrrrrrrrr}
\hline & \multicolumn{10}{c}{$\mathrm{CH}_{2} \mathrm{I}_{2}$} \\
\hline & $\mathrm{n}$ & $\mathrm{M} 1$ & $\mathrm{M} 2$ & $\mathrm{M} 3$ & $\mathrm{M} 4$ & $\mathrm{M} 5$ & M6 & M7 & M8 & M9 & mean \\
\hline${\text { Chlorophyll } a^{\mathrm{a}}}^{2}$ & 24 & $0.92^{*}$ & $0.97^{* *}$ & $0.98^{*}$ & $0.85^{*}$ & 0.75 & 0.77 & $0.91^{*}$ & $0.88^{*}$ & 0.66 & $0.77^{* *}$ \\
Total bacteria $^{\mathrm{a}}$ & 24 & $0.85^{* *}$ & $0.94^{* *}$ & $0.91^{* *}$ & 0.51 & $0.96^{* *}$ & $0.96^{* *}$ & $0.93^{* *}$ & $0.91^{* *}$ & $0.94^{* *}$ & $0.95^{* *}$ \\
Fucoxanthin $^{\mathrm{b}}$ & 6 & $0.97^{* *}$ & $0.92^{*}$ & $0.96^{*}$ & $0.83^{*}$ & $0.92^{*}$ & $0.98^{* *}$ & $0.83^{*}$ & $0.91^{*}$ & $0.83^{*}$ & $0.71^{*}$ \\
Peridinin $^{\mathrm{b}}$ & 6 & 0.61 & $0.80^{*}$ & 0.20 & 0.22 & $0.96^{* *}$ & $0.71^{*}$ & $0.88^{*}$ & $0.77^{*}$ & $0.90^{* *}$ & $0.98^{* *}$ \\
\hline
\end{tabular}

$\mathrm{a}=$ PI-PIII $\left(t_{4}-t_{27}\right)$,

$\mathrm{b}=$ PIII $\left(t_{22}-t_{30}\right)$.

Table 6. Correlation coefficients $(R)$ for relationship between $\mathrm{CHBr}_{3}$ and total bacteria, $\mathrm{CHBr}_{3}$ net loss rates, and mean $p \mathrm{CO}_{2}$ for period $t_{21}-t_{27}$. Asterisks indicate associated probability of rates, ${ }^{*}=p<0.05,{ }^{* *}=p<0.01$.

\begin{tabular}{lrrr}
\hline$t_{21}-t_{27}$ & $\begin{array}{r}R \\
{\left[\mathrm{CHBr}_{3}\right] \text { and }} \\
\text { total bacteria }\end{array}$ & $\begin{array}{r}\mathrm{CHBr}_{3} \text { net loss } \\
\text { rate }\left(\mathrm{pmol} \mathrm{L}^{-1} \mathrm{~d}^{-1}\right) \\
( \pm \mathrm{SE})\end{array}$ & $\begin{array}{r}\text { mean } \\
p \mathrm{CO}_{2} \\
(\mu \mathrm{atm})\end{array}$ \\
\hline M1 & $-0.92^{*}$ & $8.02( \pm 0.99)^{* *}$ & 535.8 \\
M2 & $-0.98^{* *}$ & $4.72( \pm 0.89)^{* *}$ & 234.6 \\
M3 & $-0.87^{*}$ & $2.26( \pm 0.80)^{*}$ & 169.8 \\
M4 & $-0.91^{*}$ & $5.10( \pm 0.95)^{* *}$ & 311.4 \\
M5 & $-0.78^{*}$ & $3.95( \pm 1.24)^{*}$ & 748.4 \\
M6 & $-0.92^{* *}$ & $3.24( \pm 0.57)^{* *}$ & 580.2 \\
M7 & $-0.88^{* *}$ & $4.31( \pm 1.06)^{* *}$ & 170.3 \\
M8 & $-0.98^{* *}$ & $2.85( \pm 0.33)^{* *}$ & 390.5 \\
M9 & $-0.79^{*}$ & $5.56( \pm 1.62)^{*}$ & 891.1 \\
\hline
\end{tabular}

Due to its high reactivity and short photolytic lifetime, $\mathrm{CH}_{2} \mathrm{I}_{2}$ is potentially one of the most important sources of iodine atoms to the coastal marine boundary layer (Carpenter et al., 1999). Thus, changes to the seato-air flux of this compound could have implications for the catalytic destruction of tropospheric ozone (Chameides and Davis, 1980) and for new particle formation (O'Dowd et al., 2002). Mean fluxes ranged from -0.02 (M6) to $4.1 \mathrm{pmol} \mathrm{m}^{-2} \mathrm{~d}^{-1}$ (M4) during PI (overall mean $1.06 \mathrm{pmol} \mathrm{m}^{-2} \mathrm{~d}^{-1}$ ), and 7.1 (M6) to $34.4 \mathrm{pmol} \mathrm{m}^{-2} \mathrm{~d}^{-1}$ (M1) in PII (overall mean $12.3 \mathrm{pmol} \mathrm{m}^{-2} \mathrm{~d}^{-1}$ ). During PIII, an increase in flux was seen in all mesocosms, with an overall mean of $30.3 \mathrm{pmol} \mathrm{m}^{-2} \mathrm{~d}^{-1}$, and a range of 24.8 (M7) to 37.3 (M9) $\mathrm{pmol} \mathrm{m}^{-2} \mathrm{~d}^{-1}$. There are a number of weaknesses in the calculation of the flux - not least the atmospheric values (Schall and Heumann, 1993), so conclusions should be drawn with caution. In PI and PII, no significant differences in flux were detected between mesocosms. Figure $4 \mathrm{c}$ shows the estimated mean cumulative fluxes for PIII plotted as a function of $p \mathrm{CO}_{2}$, showing a significant relationship ( $p=0.04)$ with increasing $p \mathrm{CO}_{2}$.

\subsubsection{Bromoform $\left(\mathrm{CHBr}_{3}\right)$}

$\mathrm{CHBr}_{3}$ is the most abundant form of volatile organic bromine in seawater (Carpenter and Liss, 2000; Quack et al., 2007; Hughes et al., 2009), and predictably dominated the concentrations of bromocarbons in the mesocosms (Fig. 2f-2j). No relationship between $\mathrm{CHBr}_{3}$ concentrations and $p \mathrm{CO}_{2}$ treatment was observed, and there was a high degree of similarity in concentrations in the majority of mesocosms.

A key feature of the $\mathrm{CHBr}_{3}$ data were the consistently higher concentrations observed in M1, most apparent from $t_{12}$ to $t_{19}$, and from $t_{20}$ to $t_{27}$ (Fig. 2f). The elevated concentrations occurred immediately after a period of rapid net production in all mesocosms. Significant net production rates were detected in $\mathrm{M} 1$ for the periods $t_{10}-t_{13}\left(22.3 \pm 4.1 \mathrm{pmol} \mathrm{d}^{-1}, p=0.03\right)$ and $t_{19}-t_{21}$ $\left(33.0 \pm 1.9 \mathrm{pmol} \mathrm{d}^{-1}, p=0.04\right)$, significantly higher than the net production rates of the remaining mesocosms. These periods of net production were immediately followed by net loss over $t_{13}-t_{16}$, and $t_{21}-t_{27}$ in all mesocosms, during which M1 displayed the greatest rates of net loss $\left(12.6 \pm 1.8 \mathrm{pmol} \mathrm{d}^{-1}, p=0.02\right.$ and $8.0 \pm 1.0 \mathrm{pmol} \mathrm{d}^{-1}$, $p=0.001$, respectively). This suggests enhanced production and turnover of $\mathrm{CHBr}_{3}$ in M1 relative to the other mesocosms.

During the final phase of the experiment significant net loss rates were observed in all mesocosms, ranging from the maximum in M1 (see above) to a minimum of $2.9 \pm 0.3 \mathrm{pmol} \mathrm{d}^{-1}$ in M8 over $t_{21}-t_{27}$ (Table 6). There was found to be no relationship between the net loss rates and $p \mathrm{CO}_{2}$ for this period of the experiment (Fig. 5a). This period of net loss coincided with strong negative correlations between $\mathrm{CHBr}_{3}$ and total bacteria, with correlation coefficients $(R)$ ranging from 0.78 to 0.98 (Table 6). Excluding the possibility of an effect of $p \mathrm{CO}_{2}$, the potential mechanisms responsible for the differences in net production and loss of $\mathrm{CHBr}_{3}$ between the mesocosms were investigated further. In seawater, a number of processes act as sinks for $\mathrm{CHBr}_{3}$ including (i) hydrolysis, (ii) reductive dehalogenation, (iii) halogen substitution, and (iv) photolysis. With half-lives at Arctic seawater temperatures of $680-1000 \mathrm{yr}$ and $74 \mathrm{yr}$ respectively, 

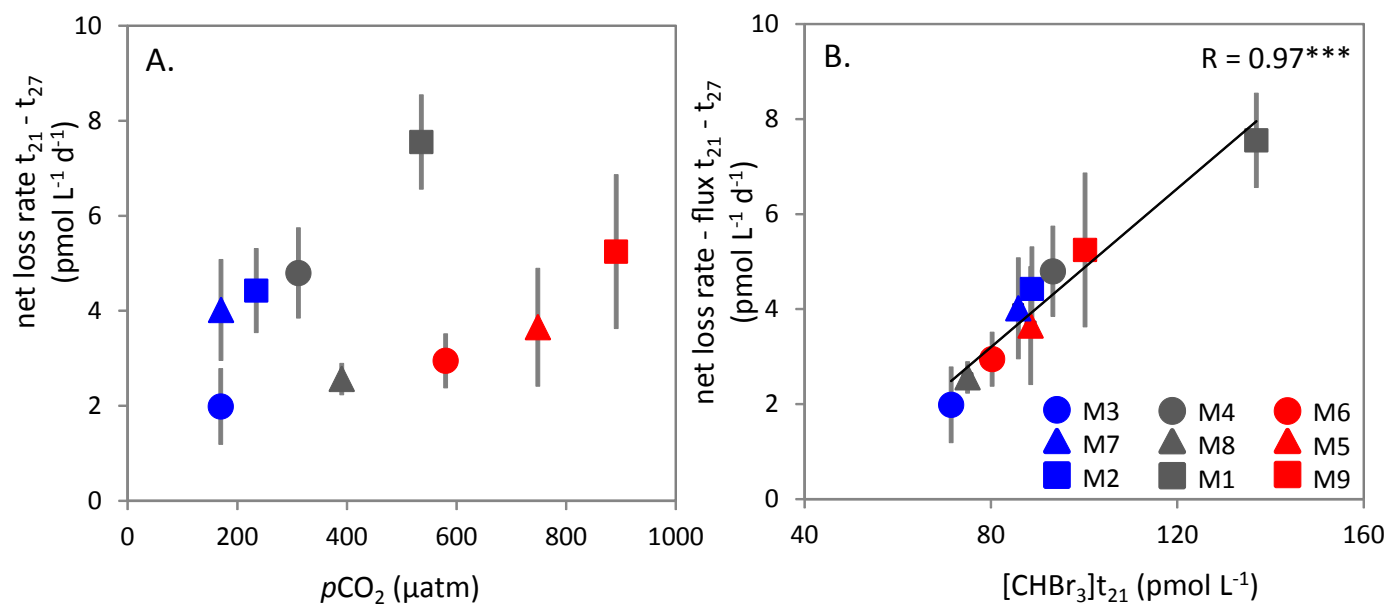

Fig. 5. Relationship between (A) net loss rates of $\mathrm{CHBr}_{3}\left(\mathrm{pmold}^{-1}\right)$ over the period $t_{21}-t_{27}$ and mean $p \mathrm{CO}_{2}(\mu \mathrm{atm})$, (B) net loss rates of $\mathrm{CHBr}_{3}$ minus the sea-to-air flux (pmol d ${ }^{-1}$ ) over the period $t_{21}-t_{27}$ and the concentrations of $\mathrm{CHBr}_{3}$ on $t_{21}$. Asterisks denote significance level of correlation $(R){ }^{* * *}=p<0.001$.

(i) and (iii) are of little importance in this discussion (Quack and Wallace, 2003). Reductive dehalogenation (ii) can occur in anaerobic conditions so is also not relevant to the mesocosms (Quack and Wallace, 2003; Vogel et al., 1987). Microbial degradation has not been directly observed (Goodwin et al., 1997), although there is some evidence that it may occur at reasonable rates within the water column of both polar and tropical waters (Hughes et al., 2009; Quack et al., 2007). Photolysis is considered to be the largest internal sink for $\mathrm{CHBr}_{3}$ (Carpenter and Liss, 2000); however this constitutes only $\sim 2 \%$ of the sea-to-air flux. The mean estimated flux of $\mathrm{CHBr}_{3}$ for all mesocosms, when scaled as described for $\mathrm{CH}_{3} \mathrm{I}$, was $0.30 \mathrm{pmol} \mathrm{L}^{-1} \mathrm{~d}^{-1}\left(\min .0 .26 \mathrm{pmol} \mathrm{L}^{-1} \mathrm{~d}^{-1}\right.$ (M8), max. $0.36 \mathrm{pmol} \mathrm{L}^{-1} \mathrm{~d}^{-1}$ (M1)), with little difference between mesocosms, and no effect of $p \mathrm{CO}_{2}$. Therefore, these estimated fluxes can explain between $5 \%$ and $12 \%$ of the net loss.

Using this information, it is possible to speculate on the dominant processes controlling the concentration of $\mathrm{CHBr}_{3}$ in the mesocosms. A key feature of the $\mathrm{CHBr}_{3}$ data was a strong and significant relationship between the observed net loss rates (corrected for the sea-to-air flux) over $t_{21}-t_{27}$ and the seawater concentrations of $\mathrm{CHBr}_{3}$ on $t_{21}$ (Fig. 5b). This apparent concentration-dependence of loss rates may indicate that the turnover of $\mathrm{CHBr}_{3}$ in the mesocosms is related to biological processes, with the linear relationship representing the biological uptake rate kinetics. This is supported by the observed significant relationships between $\mathrm{CHBr}_{3}$ concentrations and total bacteria abundances (Table 6). However, this process is apparently not sensitive to the altered $p \mathrm{CO}_{2}$ conditions.

\subsection{Comparison to a previous mesocosm experiment}

Concentrations of a variety of halocarbons from a $\mathrm{CO}_{2}$ enrichment experiment performed in temperate, coastal waters off Bergen, Norway in 2006 were reported by Hopkins et al. (2010). During the 2006 experiment, maximum chl $a$ concentrations of $6-11 \mu \mathrm{g} \mathrm{L}^{-1}$ were more than double of those measured in this study, and the plankton community showed a strong response to $\mathrm{CO}_{2}$, with significant decreases in chl $a$ and microbial plankton under high $\mathrm{CO}_{2}$. Nevertheless, both the concentrations and the general response of the bromocarbons to biological activity and $p \mathrm{CO}_{2}$ showed some similarity to the present study conducted in Arctic waters. In contrast, concentrations of iodocarbons were markedly higher during the 2006 experiment, particularly for $\mathrm{CH}_{2} \mathrm{I}_{2}$ and $\mathrm{CH}_{2} \mathrm{ClI}$ with maximum concentrations of $\sim 700$ and $\sim 600 \mathrm{pmol} \mathrm{L}^{-1}$, respectively. Furthermore, large, and in some cases significant, reductions in concentrations of all iodocarbons occurred at higher $p \mathrm{CO}_{2}\left(\mathrm{CH}_{3} \mathrm{I}:-44 \%, \mathrm{C}_{2} \mathrm{H}_{5} \mathrm{I}:-35 \%, \mathrm{CH}_{2} \mathrm{I}_{2}:-27 \%\right.$, $\mathrm{CH}_{2}$ ClI: $-24 \%$ ). The temporal dynamics of the iodocarbons suggested a close association with the plankton communities. The lower biomass and relatively lower biological activity observed in this Arctic experiment may have suppressed a clear response in the iodocarbon concentrations to increasing $\mathrm{CO}_{2}$ of the kind seen in the 2006 experiment.

\section{Conclusions}

Concentrations of a range of halocarbons were measured during a 5-week $\mathrm{CO}_{2}$-perturbation mesocosm experiment in Kongsfjorden, Spitsbergen, during June and July 2010. The temporal standing stocks of the majority of halocarbons did not significantly respond to $p \mathrm{CO}_{2}$ over a range from $\sim 175 \mu \mathrm{atm}$ to $\sim 1085 \mu \mathrm{atm}$. Halocarbon concentrations did 
show a large number of significant correlations with a range of biological parameters, suggesting some influence of the biological communities on the production and consumption of these trace gases in Arctic waters. The temporal dynamics of $\mathrm{CH}_{3} \mathrm{I}$, combined with strong correlations with biological parameters, indicated a biological control on concentrations of this gas. However, despite a $\mathrm{CO}_{2}$ effect on various components of the community, no effect of $p \mathrm{CO}_{2}$ was seen on $\mathrm{CH}_{3} \mathrm{I}$. $\mathrm{CH}_{2} \mathrm{I}_{2}$ concentrations were closely related to chl $a$ and total bacteria over the whole experiment and with the phytoplankton pigments fucoxanthin and peridinin during PIII, strongly suggesting biological production of this gas. Both the concentrations and the net production of $\mathrm{CH}_{2} \mathrm{I}_{2}$ showed some sensitivity to $p \mathrm{CO}_{2}$, with a significant increase in net production rate and sea-to-air flux at higher $p \mathrm{CO}_{2}$, particularly during the later stages of the experiment. The temporal dynamics of $\mathrm{CHBr}_{3}$ indicated rapid turnover of this gas, and concentrations varied between mesocosms, although not explainable by $p \mathrm{CO}_{2}$ treatment. Instead, net loss rates (corrected for loss via gas exchange) displayed a degree of concentration-dependence, and strong negative correlations with bacteria during periods of net loss suggest a degree of bacterial consumption of $\mathrm{CHBr}_{3}$ in Arctic waters. The results of the first Arctic OA mesocosm experiment provide invaluable information on the production and cycling of halocarbons in Arctic waters, demonstrating strong associations with the biological communities. Although the effects of OA on halocarbons concentrations were in general subtle, some significant affects were observed. The role of halocarbons in Arctic atmospheric chemistry may increase in importance in the coming decades due to increases in open water with the loss of sea ice (Mahajan et al., 2010; Stroeve et al., 2011); this work enhances our understanding of the marine production and cycling of halocarbons in a region set to experience rapid environmental change.

Acknowledgements. This work is a contribution to the European Project on OCean Acidification (EPOCA) which received funding from the European Community's Seventh Framework Programme (FP7/2007-2013) under grant agreement no. 211384. We gratefully acknowledge the logistical support of Greenpeace International for its assistance with the transport of the mesocosm facility from Kiel to Ny-Ålesund and back to Kiel. We also thank the captains and crews of M/V ESPERANZA of Greenpeace and R/V Viking Explorer of the University Centre in Svalbard (UNIS) for assistance during mesocosm transport and during deployment and recovery in Kongsfjorden. We thank Signe Koch Klavsen for providing phytoplankton pigment data and Matthias Fischer for UV measurements through the mesocosm foil. We are grateful to the UK Natural Environmental Research Council for the accommodation and support provided through the NERC-BAS station in Ny-Ålesund. We also thank the staff of the French-German Arctic Research Base at Ny-Ålesund, in particular Marcus Schuhmacher, for on-site logistical support. Financial support was provided through the European Centre for Arctic Environmental Research (ARCFAC) (grant number ARCFAC026129-2009-140) and through Transna- tional Access funds by the EU project MESOAQUA under grant agreement no. 22822. Finally, we would like to thank Ulf Riebesell, Sebastian Krug and the whole of the Svalbard mesocosm team, who showed great team spirit and comradeship and helped to make the experiment both enjoyable and successful.

Edited by: J. Middelburg

\section{References}

Amachi, S.: Microbial contribution to global iodine cycling: Volatilization, accumulation, redcution, oxidation and sorption of iodine, Microbes Environ., 23, 269-276, 2008.

Amachi, S., Kamagata, Y., Kanagawa, T., and Muramatsu, Y.: Bacteria mediate methylation of iodine in marine and terrestrial environments, Appl. Environ. Microb., 67, 2718-2722, 2001.

Bellerby, R. G. J., Silyakova, A., Nondal, G., Slagstad, D., Czerny, J., de Lange, T., and Ludwig, A.: Marine carbonate system evolution during the EPOCA Arctic pelagic ecosystem experiment in the context of simulated Arctic ocean acidification, Biogeosciences Discuss., 9, 15541-15565, doi:10.5194/bgd-9-155412012, 2012.

Brussaard, C. P. D., Noordeloos, A. A. M., Witte, H., Collenteur, M. C. J., Schulz, K., Ludwig, A., and Riebesell, U.: Arctic microbial community dynamics influenced by elevated $\mathrm{CO}_{2}$ levels, Biogeosciences, 10, 719-731, doi:10.5194/bg-10-719-2013, 2013.

Calderia, K. and Wickett, M. E.: Anthropogenic carbon and ocean pH, Nature, 425, p. 365, doi:10.1038/425365a, 2003.

Calvert, J. G. and Lindberg, S. E.: Potential influence of iodinecontaining compounds on the chemistry of the troposphere in the polar spring. I. Ozone depletion, Atmos. Environ., 38, 50875104, 2004a.

Carpenter, L. J. and Liss, P. S.: On temperature sources of bromoform and other reactive organic bromine gases, J. Geophys. Res., 105, 20539-20547, 2000.

Carpenter, L. J., Sturges, W. G., Penkett, S. A., Liss, P. S., Alicke, B., Hebestreit, K., and Platt, U.: Short lived alkyl iodides and bromides at Mace Head, Ireland: Links to biogenic sources and halogen oxide production, J. Geophys. Res., 104: 1679-1689, 1999.

Chameides, W. L. and Davis, D. D.: Iodine: Its Possible Role in Tropospheric Photochemistry, J. Geophys. Res.-Atmos., 85, 73837398, 1980.

Czerny, J., Schulz, K. G., Ludwig, A., and Riebesell, U.: Technical Note: A simple method for air-sea gas exchange measurements in mesocosms and its application in carbon budgeting, Biogeosciences, 10, 1379-1390, doi:10.5194/bg-10-1379-2013, 2013.

Davis, D., Crawford, J., Liu, S., McKeen, S., Bandy, A., Thornton, D., Rowland, F., and Blake, D.: Potential impact of iodine on tropospheric levels of ozone and other critical oxidants, J. Geophys. Res., 101, 2135-2147, 1996.

DeBruyn, W. J. and Saltzman, E. S.: Diffusivity of methyl bromide in water, Mar. Chem., 56, 51-57, 1997.

Elliott, S. and Rowland, F. S.: Nucleophilic substitution rates and solubilities for methyl halides in seawater, Geophys. Res. Lett., 20, 1043-1046, 1993.

Fenical, W.: Natural products chemistry in the marine environment, Science, 215, 923-928, 1982. 
Fuse, H., Inoue, H., Murakami, K., Takimura, O., and Yamaoka, Y.: Production of free and organic iodine by Roseovarius spp., FEMS Microbiol. Lett., 229, 189-194, 2003.

Goodwin, K. D., Lidstrom, M. E., and Oremland, R. S.:Marine bacterial degradated of brominated methanes, Environ. Sci. Technol., 31, 3188-3192, 1997.

Goodwin, K. D., Schaefer, J. K., and Oremland, R. S.: Bacterial oxididation of dibromomethane and methyl bromide in natural waters and enrichment cultures, Appl. Environ. Microb., 64, 46294636, 1998.

Goodwin, K. D., Varner, R. K., Crill, P. M., and Oremland, R. S.: Consumption of tropospheric levels of methyl bromide by $\mathrm{C}-1$ compound-utilizing bacteria and comparison to saturation kinetics, Appl. Environ. Microb., 67, 5437-5443, 2001.

Happell, J. D. and Wallace, D. W. R.: Methyl iodide in the Greenland/Norwegian Seas and the tropical Atlantic Ocean: Evidence for photochemical production, Geophys. Res. Lett., 23, 21052108, 1996.

Hopkins, F. E., Turner, S. M., Nightingale, P. D., Steinke, M., and Liss, P. S.: Ocean acidification and marine biogenic trace gas production, P. Natl. Acad. Sci. USA, 107, 760-765, 2010.

Hughes, C.: Biogenic iodocarbon production in the sea. PhD Thesis, University of East Anglia, Norwich, Norfolk, UK, 2004.

Hughes, C., Malin, G., Nightingale, P. D., and Liss, P. S.: The effect of light stress on the release of volatile iodocarbons by three species of marine microalgae, Limnol. Oceanogr. Notes, 51, 2849-2854, 2006.

Hughes, C., Malin, G. Turley, C. M., Keely, B. M., and Nightingale, P. D.: The production of volatile iodocarbons by biogenic marine aggregates, Limnol. Oceanogr., 53, 867-872, 2008.

Hughes, C., Chuck, A. L., Rossetti, H., Mann, P. J., Turner, S. M., Clarke, A., Chance, R., and Liss, P. S.: Seasonal cycle of seawater bromoform and dibromomethane concentrations in a coastal bay on the western Antarctic Peninsula, Global Biogeochem. Cy., 23, GB2024, doi:10.1029/2008GB003268, 2009.

Jones, C. E. and Carpenter, L. J.: Solar photolysis of $\mathrm{CH}_{2} \mathrm{I}_{2}$, $\mathrm{CH}_{2} \mathrm{ICl}$, and $\mathrm{CH}_{2} \mathrm{IBr}$ in water, saltwater and seawater, Environ. Sci. Technol., 39, 6130-6137, 2005.

Kahru, M., Brotas, V., Manzano-Sarabia, M., and Mitchell, B. G.: Are phytoplankton blooms occurring earlier in the Arctic?, Global Change Biol., 17, 1733-1739, 2011.

King, D. B. and Saltzman, E. S.: Removal of methyl bromide in coastal seawater: chemical and biological rates, J. Geophys. Res., 102, 18715-18721, 1997

Leblanc, C., Colin, C., Cosse, A., Delage, L., Barre, S.L., Morin, P., Fievet, B., Voiseux, C., Ambroise, Y., Verhaeghe, E., Amouroux, D., Donard, O., Tessier, E., and Potin, P.: Iodine transfer in the coastal marine environment: the key role of brown algae and of their vanadium-dependent haloperoxidasesm, Biochimie, 88, 1773-1785, 2006.

Mahajan, A. S., Shaw, M., Oetjen, H., Hornsby, K. E., Carpenter, L. J., Kaleschke, L., Tian-Kunze, X., Lee, J. D., Moller, S. J., Edwards, P., Commane, R., Ingham, T. H., Heard, D. E., and Plane, J. M. C.: Evidence of reactive iodine chemistry in the Arctic boundary layer, J. Geophys. Res., 115, D20303, 2010.

Manley, S. L.: Phytogenesis of halomethanes: a product of selection or a metabolic accident?, Biogeochemistry, 60, 163-180, 2002.

Manley, S. L. and de la Cuesta, J. L.: Methyl iodide production from marine phytoplankton cultures, Limnol. Oceanogr., 42, 142-147,
1997.

Marie, D., Brussaard, C. P. D., Partensky, F., and Vaulot, D.: Enumeration of phytoplankton, bacteria and viruses in marine samples, in: Current protocols in cytometry, edited by: Robinson, J. P., Darzynkiewicz, Z., Dean, P. N., Rabinovitch, P. S., Stewart, C. C., Tanke, H. J., and Wheeless, L. L., John Wiley and Sons, 11.11.11-11.11.15, 1999.

Markus, T., Stroeve, J., and Miller, J.: Recent changes in Arctic sea ice melt onset, freezeup, and melt season length, J. Geophys. Res., 114, C12024, doi:10.1029/2009JC005436, 2009.

Martino, M., Liss, P. S., and Plane, J. M. C.: The photolysis of dihalomathanes in surface seawater, Environ. Sci. Technol., 39, 7097-7101, 2005

Martino, M., Liss, P. S., and Plane, J. M. C.: Wavelengthdependence of the photolysis of diiodomethane in seawater, Geophys. Res. Lett., 33, L06606, doi:10.1029/2005GL025424, 2006.

Martino, M., Mills, G. P., Woeltjen, J., and Liss, P. S.: A new source of volatile organoiodine compounds in surface seawater, Geophys. Res. Lett., 36, L01609, doi:10.1029/2008GL036334, 2009.

Moore, R. M. and Grosko, W.: Mehtyl iodide distribution in the ocean and fluxes to the atmosphere, J. Geophys. Res., 104, 11163-11171, 1999.

Moore, R. M. and Zafiriou, O. C.: Photochemical production of methyl iodide in seawater, J. Geophys. Res., 99, 16415-16420, 1994.

Moore, R. M., Geen, C. E., and Tait, V. K.: Determination of Henry's Law Constants for a suite of naturally occurring halogenated methanes in seawater, Chemosphere, 30, 1183-1191, 1995.

Moore, R. M., Webb, M., and Tokarczyk, R.: Bromoperoxidase and iodoperoxidase enzymes and production of halogenated methanes in marine diatom cultures, J. Geophys. Res., 101, 20899-20908, 1996.

O’Dowd, C. D., Jimenez, J. L., Bahreini, R., Flagan, R. C., Seinfeld, J. H., Hämeri, K., Pirjola, L., Kulmala, M., Jennings, S. G., and Hoffmann, T.: Marine aerosol formation from biogenic iodine emissions, Nature, 417, 632-636, 2002.

Orr, J. C., Fabry, V. J., Aumont, O., Bopp, L., Doney, S. C., Feely, R. A., Gnanadesikan, A., Gruber, N., Ishida, A., Joos, F., Key, R. M, Lindsay, K., Maier-Reimer, E., Matear, R., Monfray, P., Mouchet, A., Najjar, R. G., Plattner, G.-K., Rodgers, K. B., Sabine, C. L., Sarmiento, J. L., Schlitzer, R., Slater, R. D., Totterdell, I. J., Weirig, M.-F., Yamanaka, Y., and Yool, A.: Anthropogenic ocean acidification over the twenty-first century and its impact on calcifying organisms, Nature 437, 681-686, 2005.

Piontek, J., Lunau, M., Händel, N., Borchard, C., Wurst, M., and Engel, A.: Acidification increases microbial polysaccharide degradation in the ocean, Biogeosciences, 7, 1615-1624, doi:10.5194/bg-7-1615-2010, 2010.

Quack, B. and Wallace, D. W. R.: Air-sea flux of bromoform: Controls, rates, and implications, Global Biogeochem. Cy., 17, 1023, doi:10.1029/2002GB001890, 2003.

Quack, B., Peeken, I., Petrick, G., and Nachtingall, K.: Oceanic distribution and sources of bromoform and dibromomethane in the Mauritanian upwelling, J. Geophys. Res., 112, C10006, doi:10.1029/2006JC003803, 2007.

Read, K. A., Mahajan, A. S., Carpenter, L. J., Evans, M. J., Faria, B. V. E., Heard, D. E., Hopkins, J. R., Lee, J. D., Moller, S. J., Lewis, A. C., Mendes, L., McQuaid, J. B., Oetjen, H., Saiz-Lopez, A., 
Pilling, M. J., and Plane, J. M. C.: Extensive halogen-mediated ozone destruction over the tropical Atlantic Ocean, Nature, 453, 1232-1235, 2008.

Richter, U. and Wallace, D. W. R.: Production of methyl iodide in the tropical Atlantic Ocean, Geophys. Res. Lett., 31, L23S03, doi:10.1029/2004GL020779, 2004.

Riebesell, U. and Tortell, P. D.: Effects of ocean acidification on pelagic organisms and ecosystems, in: Ocean Acidification, edited by: Gattuso, J. P. and Hanson, L., Oxford University Press, Oxford, 99-121, 2011.

Sabine, C., Feely, R. A., Gruber, N., Key, R. M., Lee, K., Bullister, J. L., Wanninkhof, R., Wong, C. S., Wallace, D. W. R., Tilbrook, B., Millero, F. J., Peng, T.-H., Kozyr, A., Ono, T., and Rios, A. F.: The oceanic sink for anthropogenic $\mathrm{CO}_{2}$, Science, 305, 367-371, 2004.

Saiz-Lopez, A., Plane, J. M. C., Mahajan, A. S., Anderson, P. S., Bauguitte, S. J.-B., Jones, A. E., Roscoe, H. K., Salmon, R. A., Bloss, W. J., Lee, J. D., and Heard, D. E.: On the vertical distribution of boundary layer halogens over coastal Antarctica: implications for $\mathrm{O}_{3}, \mathrm{HO}_{\mathrm{x}}, \mathrm{NO}_{\mathrm{x}}$ and the $\mathrm{Hg}$ lifetime, Atmos. Chem. Phys., 8, 887-900, doi:10.5194/acp-8-887-2008, 2008.

Scarratt, M. G. and Moore, R. M.: Production of methyl bromide and methyl chloride in laboratory cultures of marine phytoplankton II, Mar. Chem., 59, 311-320, 1998.

Schall, C. and Heumann, K. G.: GC determination of volatile organoiodine and organobromine compounds in Arctic seawater and air samples, Fresen. J. Anal. Chem., 346, 717-722, 1993.

Schulz, K. G., Bellerby, R. G. J., Brussaard, C. P. D., Büdenbender, J., Czerny, J., Engel, A., Fischer, M., Koch-Klavsen, S., Krug, S. A., Lischka, S., Ludwig, A., Meyerhöfer, M., Nondal, G., Silyakova, A., Stuhr, A., and Riebesell, U.: Temporal biomass dynamics of an Arctic plankton bloom in response to increasing levels of atmospheric carbon dioxide, Biogeosciences, 10, 161180, doi:10.5194/bg-10-161-2013, 2013.

Shaw, M. D., Carpenter, L. J., Baeza-Romero, M. T., and Jackson, A. V.: Thermal evolution of diffusive transport of atmospheric halocarbons through artificial sea ice, Atmos. Environ., 45, 6393-6402, 2011.

Simpson, W. R., von Glasow, R., Riedel, K., Anderson, P., Ariya, P., Bottenheim, J., Burrows, J., Carpenter, L. J., Frieß, U., Goodsite, M. E., Heard, D., Hutterli, M., Jacobi, H.-W., Kaleschke, L., Neff, B., Plane, J., Platt, U., Richter, A., Roscoe, H., Sander, R., Shepson, P., Sodeau, J., Steffen, A., Wagner, T., and Wolff, E.: Halogens and their role in polar boundary-layer ozone depletion, Atmos. Chem. Phys., 7, 4375-4418, doi:10.5194/acp-74375-2007, 2007.
Solomon, S., Garcia, R. R., and Ravishankara, A. R.: On the role of iodine in ozone depletion, J. Geophys. Res., 99, 20491-20499, 1994.

Steinacher, M., Joos, F., Frölicher, T. L., Plattner, G.-K., and Doney, S. C.: Imminent ocean acidification in the Arctic projected with the NCAR global coupled carbon cycle-climate model, Biogeosciences, 6, 515-533, doi:10.5194/bg-6-515-2009, 2009.

Stroeve, J., Serreze, M., Holland, M., Kay, J., Malanik, J., and Barrett, A.: The Arctic's rapidly shrinking sea ice cover: a research sythesis, Climatic Change, 110, 1005-1027, doi:10.1007/s10584-011-0101-1, 2011.

Tait, V. K. and Moore, R. M.: Methyl chloride $\left(\mathrm{CH}_{3} \mathrm{Cl}\right)$ production in phytoplankton cultures, Limnol. Oceanogr., 40, 189-195, 1995.

Tarran, G. A. , Zubkov, M. V., Sleigh, M. A., Burkill, P. H., and Yallop, M.: Microbial community structure and standing stocks in the NE Atlantic in June and July of 1996, Deep-Sea Res. II, 48, 963-985, 2001.

Tokarczyk, R. and Moore, R. M.: Production of volatile organohalogens by phytoplankton cultures, Geophys. Res. Lett., 21, 285288, 1994.

Vogel, T. M., Criddle, C. S., and McCarty, P. L.: Transformations of halogenated aliphatic compounds, Environ. Sci. Technol., 21, 722-736, 1987.

Wang, M. and Overland, J. E.: A sea ice free summer Arctic within 30 years?, Geophys. Res. Lett., 36, L07502, doi:10.1029/2009GL037820, 2009.

Welschmeyer, N. A.: Fluorometric analysis of chlorophyll $a$ in the presence of chlorophyll $b$ and pheopigments, Limnol. Oceanogr., 39, 1985-1992, 1994.

Wingenter, O. W., Haase, K. B., Zeigler, M., Blake, D. R., Rowland, F. S., Sive, B. C., Paulino, A., Runar, T., Larsen, A., Schulz, K., Meyerhofer, M., and Riebesell, U.: Unexpected consequences of increasing $\mathrm{CO}_{2}$ and ocean acidity on marine production of DMS and $\mathrm{CH}_{2} \mathrm{ClI}$ : Potential climate impacts, Geophys. Res. Lett., 34, L05710, doi:10.1029/2006GL028139, 2007.

Zafiriou, O. C.: Reaction of methyl halides with seawater and marine aerosols, J. Mar. Res., 33, 75-81, 1975.

Zhang, J., Spitz, Y. H., Steele, M., Ashjian, C., Campbell, R., Berline, L., and Matrai, P.: Modeling the impact of declining sea ice on the Arctic marine planktonic ecosystem, J. Geophys. Res., 115, C10015, doi:10.1029/2009JC005387, 2010. 